\title{
Cleanup Verification Package for the 618-8 Burial Ground
}

\author{
Prepared for the U.S. Department of Energy \\ by Washington Closure Hanford
}




\section{EXECUTIVE SUMMARY}

This cleanup verification package documents completion of remedial action for the 618-8 Burial Ground, also referred to as the Solid Waste Burial Ground No. 8, 318-8, and the Early Solid Waste Burial Ground. This site is located in the 300-FF-2 Operable Unit in the 600 Area of the Hanford Site in southeastern Washington State. During its period of operation from 1943 to 1954 , the $618-8$ site is speculated to have been used to bury uranium-contaminated waste derived from fuel manufacturing, and construction debris from the remodeling of the 313 Building.

Site excavation and waste disposal are complete, and the exposed surfaces have been sampled and analyzed to verify attainment of the remedial action goals. Results of the sampling, laboratory analyses, and data evaluations for the 618-8 site indicate that all remedial action objectives and goals for direct exposure, protection of groundwater, and protection of the Columbia River have been met for industrial land use (Table ES-1).

Because residual soil concentrations indicated that cleanup levels for more stringent land uses may have been achieved for the 618-8 site, a supplemental evaluation was performed against unrestricted land-use cleanup objectives established in the Explanation of Significant Differences for the 300-FF-2 Operable Unit Record of Decision (EPA 2004). Results of the evaluation (Table ES-2) demonstrate that residual contaminant concentrations do not preclude any future uses (as bounded by the rural-residential scenario) and allow for unrestricted use of shallow zone soils (i.e., surface to $4.6 \mathrm{~m}$ [15 ft] deep). This site does not have a deep zone; therefore, no deep zone institutional controls are required.

The site meets cleanup standards and has been reclassified as "interim closed out" in accordance with the Hanford Federal Facility Agreement and Consent Order (Ecology et al. 1989) and the Waste Site Reclassification Guideline TPA-MP-14 (RL-TPA-90-0001) (DOE-RL 1998). A copy of the waste site reclassification form is included as Attachment ES-1. 
Table ES-1. Summary of Cleanup Verification Results for the 618-8 Waste Site - Industrial Land Use. (2 pages)

\begin{tabular}{|c|c|c|c|c|}
\hline $\begin{array}{l}\text { Regulatory } \\
\text { Requirement }\end{array}$ & Remedial Action Goals & Results & $\begin{array}{l}\text { Remedial } \\
\text { Action } \\
\text { Objectives } \\
\text { Attained? }\end{array}$ & Ref. \\
\hline $\begin{array}{l}\text { Direct Exposure - } \\
\text { Radionuclides }\end{array}$ & $\begin{array}{l}\text { 1. Attain } 15 \mathrm{mrem} / \mathrm{yr} \text { dose rate } \\
\text { above background over } \\
1,000 \text { years. }\end{array}$ & $\begin{array}{l}\text { 1. All individual radionuclide COC } \\
\text { detections were below } \\
\text { background. }\end{array}$ & Yes & a \\
\hline $\begin{array}{l}\text { Direct Exposure - } \\
\text { Nonradionuclides }\end{array}$ & 1. Attain individual COC RAGs. & $\begin{array}{l}\text { 1. All individual COC concentrations } \\
\text { were below the direct exposure } \\
\text { criteria. }\end{array}$ & Yes & a \\
\hline \multirow[t]{4}{*}{$\begin{array}{l}\text { Nonradionuclide Risk } \\
\text { Requirements }\end{array}$} & $\begin{array}{l}\text { 1. Attain hazard quotient of }<1 \text { for } \\
\text { noncarcinogens. }\end{array}$ & \multirow{2}{*}{$\begin{array}{l}\text { 1,2. The hazard quotient for selenium, } \\
\text { the sole nonradionuclide detected } \\
\text { above background, is } 2.1 \times 10^{-3} \text {, } \\
\text { which is less than } 1 . \text { Because } \\
\text { selenium is the sole } \\
\text { nonradionuclide detected above } \\
\text { background, the cumulative } \\
\text { hazard quotient is also }<1 \text {. }\end{array}$} & \multirow{4}{*}{ Yes } & \multirow{4}{*}{ a } \\
\hline & $\begin{array}{l}\text { 2. Attain cumulative hazard quotient } \\
\text { of }<1 \text { for noncarcinogens. }\end{array}$ & & & \\
\hline & $\begin{array}{l}\text { 3. Attain excess cancer risk of } \\
<1 \times 10^{-5} \text { for individual } \\
\text { carcinogens. }\end{array}$ & \multirow{2}{*}{$\begin{array}{l}\text { 3,4. Excess cancer risk values were } \\
\text { not calculated because all } \\
\text { nonradionuclide carcinogenic } \\
\text { COCs (arsenic and cadmium) } \\
\text { were detected below statistical } \\
\text { background levels. }\end{array}$} & & \\
\hline & $\begin{array}{l}\text { 4. Attain a total excess cancer risk of } \\
<1 \times 10^{-5} \text { for carcinogens. }\end{array}$ & & & \\
\hline \multirow[t]{4}{*}{$\begin{array}{l}\text { Groundwater/River } \\
\text { Protection - } \\
\text { Radionuclides }\end{array}$} & $\begin{array}{l}\text { 1. Attain single-COC groundwater } \\
\text { and river protection RAGs. }\end{array}$ & $\begin{array}{l}\text { 1. All individual radionuclide COC } \\
\text { detections were below } \\
\text { background. }\end{array}$ & \multirow{3}{*}{ Yes } & \multirow{3}{*}{ a } \\
\hline & $\begin{array}{l}\text { 2. Attain National Primary Drinking } \\
\text { Water Standards: } 4 \mathrm{mrem} / \mathrm{yr} \\
\text { (beta/gamma) dose rate to target } \\
\text { receptor/organs. }\end{array}$ & $\begin{array}{l}\text { 2. All individual radionuclide COC } \\
\text { detections were below } \\
\text { background. }\end{array}$ & & \\
\hline & $\begin{array}{l}\text { 3. Meet drinking water standards for } \\
\text { alpha emitters: the more stringent } \\
\text { of the } 15 \mathrm{pCi} / \mathrm{L} \mathrm{MCL} \text { or } 1 / 25 \text { th of } \\
\text { the derived concentration guide } \\
\text { per DOE Order } 5400.5 \text {. }\end{array}$ & $\begin{array}{l}\text { 3. All individual radionuclide COC } \\
\text { detections were below } \\
\text { background. }\end{array}$ & & \\
\hline & $\begin{array}{l}\text { 4. Meet total uranium standard of } \\
21.2 \mathrm{pCi} / \mathrm{L} \text {. }\end{array}$ & $\begin{array}{l}\text { 4. Uranium statistical values are } \\
\text { below background for this site. }\end{array}$ & NA & \\
\hline $\begin{array}{l}\text { Groundwater/River } \\
\text { Protection - } \\
\text { Nonradionuclides }\end{array}$ & $\begin{array}{l}\text { 1. Attain individual nonradionuclide } \\
\text { groundwater and river cleanup } \\
\text { requirements. }\end{array}$ & $\begin{array}{l}\text { 1. Soil cleanup levels for } \\
\text { groundwater and river protection } \\
\text { have been attained. }\end{array}$ & Yes & a \\
\hline
\end{tabular}


Table ES-1. Summary of Cleanup Verification Results for the 618-8 Waste Site - Industrial Land Use. (2 pages)

\begin{tabular}{|l|l|c|c|c|}
\hline $\begin{array}{c}\text { Regulatory } \\
\text { Requirement }\end{array}$ & \multicolumn{1}{|c|}{ Remedial Action Goals } & Results & $\begin{array}{c}\text { Remedial } \\
\text { Action } \\
\text { Objectives } \\
\text { Attained? }\end{array}$ & Ref. \\
\hline $\begin{array}{l}\text { Other supporting } \\
\text { Information }\end{array}$ & 1. $618-8$ Burial Ground Sample Design (Appendix C) & $\mathrm{c}$ \\
\cline { 2 - 4 } & 2. Closeout Plan for the 618-8 Burial Ground & $\mathrm{d}$ \\
\hline
\end{tabular}

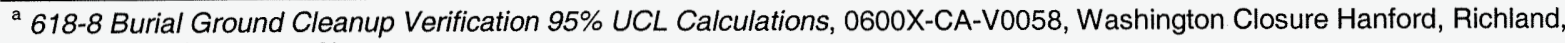
Washington (Appendix C).

${ }^{\mathrm{b}}$ The EPA has promulgated a drinking water MCL of $30 \mu \mathrm{g} / \mathrm{L}$ for total uranium (40 CFR 141.66). Based on the isotopic distribution of uranium on the Hanford Site, the $30 \mu \mathrm{g} / \mathrm{L} \mathrm{MCL}$ corresponds to $21.2 \mathrm{pCi} / \mathrm{L}$. Concentration-to-activity calculations are documented in the Calculation of Total Uranium Activity Corresponding to a Maximum Contaminant Level for Total Uranium of 30 Micrograms per Liter in Groundwater calculation brief (BHI 2001).

'618-8 Shallow Zone Sampling Plan, 0300X-CA-V0067, Washington Closure Hanford, Richland, Washington.

${ }^{\mathrm{d}}$ Closeout Plan for the 618-8 Burial Ground, CCN 126068, Washington Closure Hanford, Richland, Washington (WCH 2006b).

$\mathrm{COC}=$ contaminant of concern

$\mathrm{NA}=$ not applicable

RAG $=$ remedial action goal

$\mathrm{MCL}=$ maximum contaminant level (drinking water standard)

$\mathrm{UCL}=$ upper confidence limit

Table ES-2. Summary of Cleanup Verification Results for the 618-8 Waste Site - Unrestricted Land Use. (2 Pages)

\begin{tabular}{|c|c|c|c|c|}
\hline $\begin{array}{l}\text { Regulatory } \\
\text { Requirement }\end{array}$ & Remedial Action Goals & Results & $\begin{array}{l}\text { Remedial } \\
\text { Action } \\
\text { Objectives } \\
\text { Attained? }\end{array}$ & Ref. \\
\hline \begin{tabular}{|l|} 
Direct Exposure - \\
Radionuclides
\end{tabular} & $\begin{array}{l}\text { 1. Attain } 15 \mathrm{mrem} / \mathrm{yr} \text { dose rate } \\
\text { above background over } \\
1,000 \text { years. }\end{array}$ & $\begin{array}{l}\text { 1. All individual radionuclide } \mathrm{COC} \\
\text { detections were below } \\
\text { background. }\end{array}$ & Yes & $\mathrm{a}$ \\
\hline $\begin{array}{l}\text { Direct Exposure - } \\
\text { Nonradionuclides }\end{array}$ & 1. Attain individual COC RAGs. & $\begin{array}{l}\text { 1. All individual COC concentrations } \\
\text { were below the direct exposure } \\
\text { criteria. }\end{array}$ & Yes & $a$ \\
\hline \multirow[t]{4}{*}{$\begin{array}{l}\text { Nonradionuclide Risk } \\
\text { Requirements }\end{array}$} & $\begin{array}{l}\text { 1. Attain hazard quotient of }<1 \text { for } \\
\text { noncarcinogens. }\end{array}$ & \multirow{2}{*}{$\begin{array}{l}\text { 1,2. The hazard quotient for selenium, } \\
\text { the sole nonradionuclide detected } \\
\text { above background, is } 2.1 \times 10^{-3} \text {, } \\
\text { which is less than } 1 \text {. Because } \\
\text { selenium is the sole } \\
\text { nonradionuclide detected above } \\
\text { background, the cumulative } \\
\text { hazard quotient is also }<1 \text {. }\end{array}$} & \multirow{4}{*}{ Yes } & \multirow{4}{*}{ a } \\
\hline & $\begin{array}{l}\text { 2. Attain cumulative hazard quotient } \\
\text { of }<1 \text { for noncarcinogens. }\end{array}$ & & & \\
\hline & $\begin{array}{l}\text { 3. Attain excess cancer risk of } \\
<1 \times 10^{-6} \text { for individual } \\
\text { carcinogens. }\end{array}$ & \multirow{2}{*}{$\begin{array}{l}\text { 3,4. Excess cancer risk values were } \\
\text { not calculated because all } \\
\text { nonradionuclide carcinogenic } \\
\text { COCs (arsenic and cadmium) } \\
\text { were detected below statistical } \\
\text { background levels. }\end{array}$} & & \\
\hline & $\begin{array}{l}\text { 4. Attain a total excess cancer risk of } \\
<1 \times 10^{-5} \text { for carcinogens. }\end{array}$ & & & \\
\hline $\begin{array}{l}\text { Groundwater/River } \\
\text { Protection - } \\
\text { Radionuclides }\end{array}$ & $\begin{array}{l}\text { 1. Attain single-COC groundwater } \\
\text { and river protection RAGs. }\end{array}$ & $\begin{array}{l}\text { 1. All individual radionuclide } \mathrm{COC} \\
\text { detections were below } \\
\text { background. }\end{array}$ & Yes & $a$ \\
\hline
\end{tabular}


CVP-2006-00006

Rev. 0

Table ES-2. Summary of Cleanup Verification Results
or the 618-8 Waste Site - Unrestricted Land Use. (2 Pages)

\begin{tabular}{|c|c|c|c|c|}
\hline $\begin{array}{l}\text { Regulatory } \\
\text { Requirement }\end{array}$ & Remedial Action Goals & Results & $\begin{array}{l}\text { Remedial } \\
\text { Action } \\
\text { Objectives } \\
\text { Attained? }\end{array}$ & Ref. \\
\hline & $\begin{array}{l}\text { 2. Attain National Primary Drinking } \\
\text { Water Standards: } 4 \mathrm{mrem} / \mathrm{yr} \\
\text { (beta/gamma) dose rate to target } \\
\text { receptor/organs. }\end{array}$ & $\begin{array}{l}\text { 2. All individual radionuclide } \mathrm{COC} \\
\text { detections were below } \\
\text { background. }\end{array}$ & & \\
\hline & $\begin{array}{l}\text { 3. Meet drinking water standards for } \\
\text { alpha emitters: the more stringent } \\
\text { of the } 15 \mathrm{pCi} / \mathrm{L} \mathrm{MCL} \text { or } 1 / 25 \text { th of } \\
\text { the derived concentration guide } \\
\text { per DOE Order } 5400.5 \text {. }\end{array}$ & $\begin{array}{l}\text { 3. All individual radionuclide COC } \\
\text { detections were below } \\
\text { background. }\end{array}$ & & \\
\hline & $\begin{array}{l}\text { 4. Meet total uranium standard of } \\
21.2 \mathrm{pCi} / \mathrm{L} \text {. }\end{array}$ & $\begin{array}{l}\text { 4. Uranium statistical values are } \\
\text { below background for this site. }\end{array}$ & NA & \\
\hline $\begin{array}{l}\text { Groundwater/River } \\
\text { Protection - } \\
\text { Nonradionuclides }\end{array}$ & $\begin{array}{l}\text { 1. Attain individual nonradionuclide } \\
\text { groundwater and river cleanup } \\
\text { requirements. }\end{array}$ & $\begin{array}{l}\text { 1. Soil cleanup levels for } \\
\text { groundwater and river protection } \\
\text { have been attained. }\end{array}$ & Yes & a \\
\hline \multirow{2}{*}{$\begin{array}{l}\text { Other supporting } \\
\text { Information }\end{array}$} & \multicolumn{3}{|c|}{ 1. 618-8 Burial Ground Sample Design (Appendix C) } & c \\
\hline & \multicolumn{3}{|c|}{ 2. Closeout Plan for the $618-8$ Burial Ground } & d \\
\hline
\end{tabular}

${ }^{a}$ 618-8 Burial Ground Cleanup Verification 95\% UCL Calculations, 0600X-CA-V0058, Washington Closure Hanford, Richland, Washington (Appendix C).

${ }^{b}$ The EPA has promulgated a drinking water MCL of $30 \mu \mathrm{g} / \mathrm{L}$ for total uranium (40 CFR 141.66). Based on the isotopic distribution of uranium on the Hanford Site, the $30 \mu \mathrm{g} / \mathrm{L} \mathrm{MCL}$ corresponds to $21.2 \mathrm{pCi} / \mathrm{L}$. Concentration-to-activity calculations are documented in the Calculation of Total Uranium Activity Corresponding to a Maximum Contaminant Level for Total Uranium of 30 Micrograms per Liter in Groundwater calculation brief (BHI 2001).

${ }^{\circ}$ 618-8 Shallow Zone Sampling Plan, 0300X-CA-V0067, Washington Closure Hanford, Richland, Washington.

${ }^{d}$ Closeout Plan for the 618-8 Burial Ground, CCN 126068, Washington Closure Hanford, Richland, Washington (WCH $\left.2006 a\right)$.

$\mathrm{COC}=$ contaminant of concern

NA = not applicable

$\mathrm{RAG}=$ remedial action goal

$\mathrm{MCL}=$ maximum contaminant level (drinking water standard)

$\mathrm{UCL}=$ upper confidence limit 
CVP-2006-00006

Rev. 0

\section{Attachment ES-1 \\ Waste Site Reclassification Form}

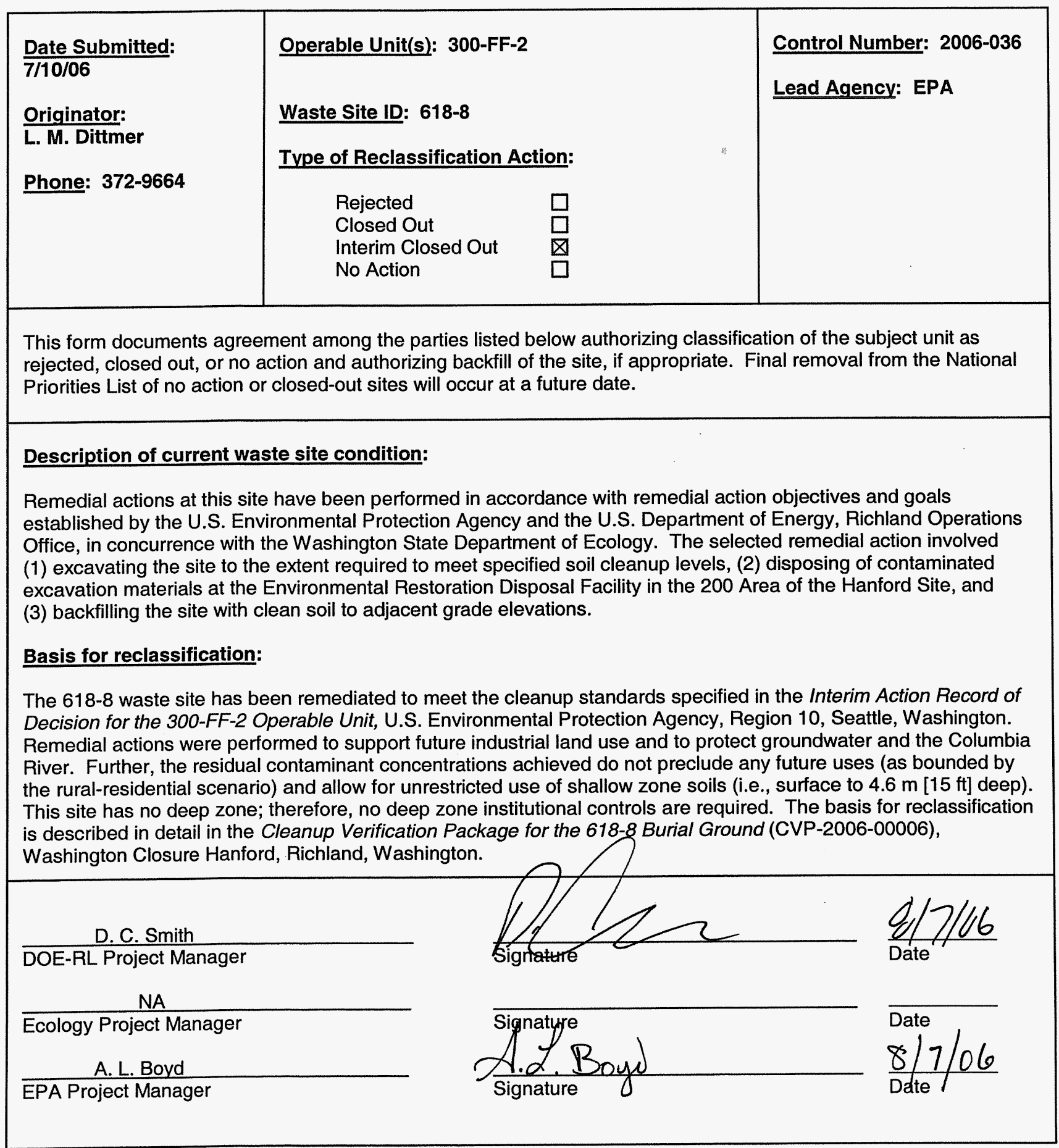


CVP-2006-00006

Rev. 0

ES-6 


\section{CONTENTS}

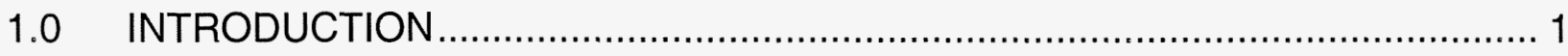

2.0 SITE DESCRIPTION AND SUPPORTING INFORMATION ............................... 3

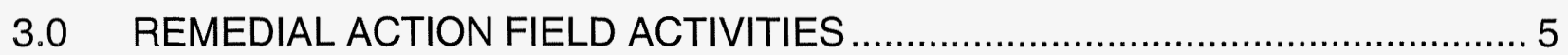

3.1 EXCAVATION AND DISPOSAL …............................................... 5

3.2 FIELD SCREENING ......................................................................

3.3 CLEANUP VERIFICATION SAMPLING AND ANALYSIS ....................10

4.0 CLEANUP VERIFICATION DATA EVALUATION …................................... 10

4.1 DATA QUALITY ASSESSMENT PROCESS ................................... 10

4.2 CONTAMINANTS OF CONCERN 95\% UPPER CONFIDENCE LIMIT... 11

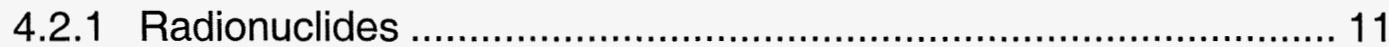

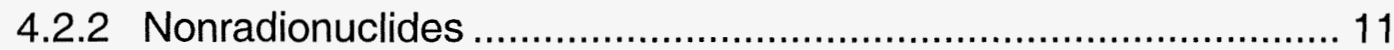

4.3 SITE-SPECIFIC CLEANUP VERIFICATION MODEL …...................... 12

4.4 RESRAD MODELING ................................................................. 12

5.0 EVALUATION OF REMEDIAL ACTION GOAL ATTAINMENT FOR

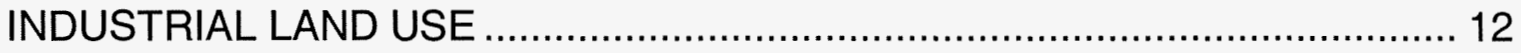

5.1 DIRECT EXPOSURE SOIL REMEDIAL ACTION GOALS ATTAINED .... 13

5.1.1 Radionuclides ................................................................... 13

5.1.2 Nonradionuclides .................................................................... 13

5.2 GROUNDWATER REMEDIAL ACTION GOALS ATTAINED ................. 14

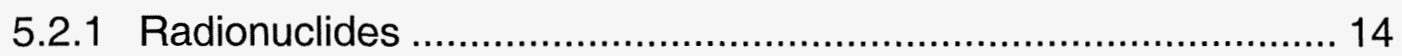

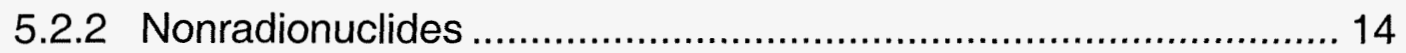

5.3 COLUMBIA RIVER REMEDIAL ACTION GOALS ATTAINED ............... 14

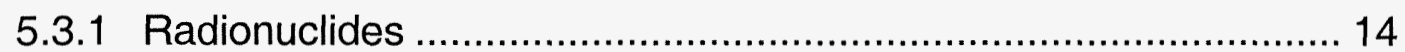

5.3.2 Nonradionuclides .................................................................. 15

5.4 WAC 173-340 THREE-PART TEST FOR NONRADIONUCLIDES ......... 15

6.0 EVALUATION OF REMEDIAL ACTION GOAL ATTAINMENT FOR

UNRESTRICTED LAND USE ……...................................................... 16

6.1 DIRECT EXPOSURE SOIL REMEDIAL ACTION GOALS ATTAINED.... 17

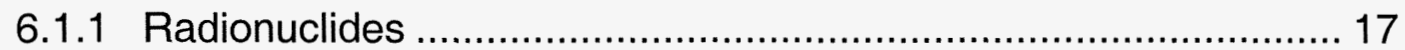

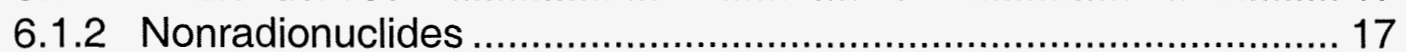

6.2 GROUNDWATER REMEDIAL ACTION GOALS ATTAINED …................ 18

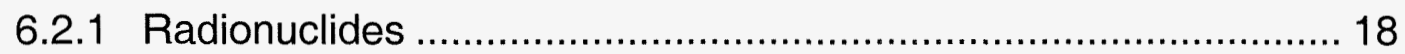

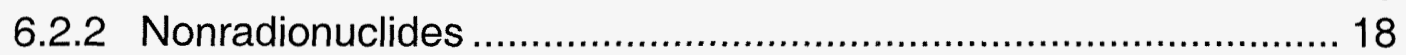

6.3 COLUMBIA RIVER REMEDIAL ACTION GOALS ATTAINED ............... 19

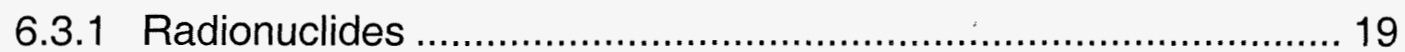

6.3.2 Nonradionuclides .................................................................... 19

6.4 WAC 173-340 THREE-PART TEST FOR NONRADIONUCLIDES ......... 19

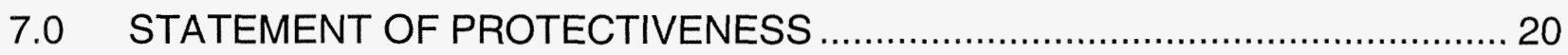

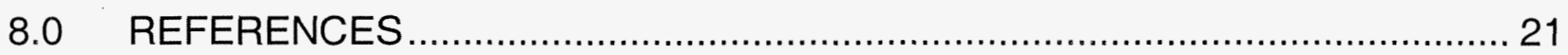




\section{APPENDICES}

A SUMMARY OF VERIFICATION SOIL SAMPLING AND ANALYTICAL RESULTS

B DATA QUALITY ASSESSMENT

C CALCULATION BRIEF EXCERPTS

C2 618-8 Burial Ground Cleanup Verification 95\% UCL

Calculations (0600X-CA-V0058)

\section{FIGURES}

1. Hanford Site Map and Location of the 618-8 Burial Ground............................... 4

2. Pre-Remediation Topographic Plan for the Western Portion of the 618-8 Waste Site.

3. Post-Remediation Topographic Plan for the Western Portion of the 618-8 Waste Site.

4. $\quad$ 618-8 Burial Ground Radiological Survey Results....................................... 8

5. 618-8 Burial Ground Radiological Survey Results.

\section{TABLES}

1. Summary of Remedial Action Goals - Industrial Land Use .............................. 1

2. Cleanup Verification Data Set ................................................................ 11

3. Attainment of Nonradionuclide Direct Exposure Standards Industrial Land Use.

4. Attainment of Nonradionuclide Groundwater and River Protection

Standards for the 618-8 Waste Site.

5. Application of the WAC 173-340 Three-Part Test.

6. Attainment of Nonradionuclide Direct Exposure Standards - Unrestricted Land Use.

7. Attainment of Nonradionuclide Groundwater and River Protection Standards for the 618-8 Waste Site.

8. Application of the WAC 173-340 Three-Part Test. 


\section{ACRONYMS AND ABBREVIATIONS}

$\begin{array}{ll}\text { COC } & \text { contaminant of concern } \\ \text { CVP } & \text { cleanup verification package } \\ \text { DQA } & \text { data quality assessment } \\ \text { EPA } & \text { U.S. Environmental Protection Agency } \\ \text { ERDF } & \text { Environmental Restoration Disposal Facility } \\ \text { GPR } & \text { ground-penetrating radar } \\ \text { MTCA } & \text { Model Toxics Control Act } \\ \text { RAG } & \text { remedial action goal } \\ \text { RAO } & \text { remedial action objective } \\ \text { RDR/RAWP } & \text { remedial design report/remedial action work plan } \\ \text { RESRAD } & \text { RESidual RADioactivity (dose assessment model) } \\ \text { ROD } & \text { record of decision } \\ \text { SAP } & \text { sampling and analysis plan } \\ \text { UCL } & \text { upper confidence limit } \\ \text { WAC } & \text { Washington Administrative Code }\end{array}$


CVP-2006-00006

Rev. 0 


\subsection{INTRODUCTION}

This cleanup verification package (CVP) documents that the 618-8 waste site was remediated in accordance with the Interim Action Record of Decision for the 300-FF-2 Operable Unit, Hanford Site, Benton County, Washington (ROD) (EPA 2001). Remedial action objectives (RAOs) and remedial action goals (RAGs) for this site are documented in the ROD (EPA 2001) and the Remedial Design Report/Remedial Action Work Plan for the 300 Area (RDR/RAWP) (DOE-RL 2004a). The ROD provides the U.S. Department of Energy, Richland Operations Office, the authority, guidance, and objectives to conduct this remedial action.

The remedy specified in the ROD for the 618-8 waste site included (1) excavating the site to the extent required to meet specified soil cleanup levels, (2) disposing of contaminated excavation materials at the Environmental Restoration Disposal Facility (ERDF) in the 200 Area of the Hanford Site, and (3) backfilling the site with clean soil to average adjacent grade elevation. Excavation was driven by RAOs for direct exposure, protection of groundwater, and protection of the Columbia River. For the respective points of compliance, RAGs summarized in Table 1 were established for the contaminants of concern (COCs) in the RDR/RAWP (DOE-RL 2004b). Preliminary waste site COCs were identified in the 300 Area Remedial Action Sampling and Analysis Plan (SAP) (DOE-RL 2004a). Following excavation of the site, final COCs were identified in the Closeout Plan for the 618-8 Burial Ground (WCH 2006a) and are presented in Table 1.

Table 1. Summary of Remedial Action Goals - Industrial Land Use. (2 Pages)

\begin{tabular}{|c|c|c|c|}
\hline Contaminants of Concern & $\begin{array}{l}\text { Soil Cleanup } \\
\text { Level for Direct } \\
\text { Exposure }^{\mathrm{a}} \\
(\mathrm{pCi} / \mathrm{g})\end{array}$ & $\begin{array}{l}\text { Soil Cleanup } \\
\text { Level for } \\
\text { Groundwater } \\
\text { Protection } \\
\text { (pCi } / \mathrm{g})\end{array}$ & $\begin{array}{c}\text { Soil Cleanup Level } \\
\text { for River Protection } \\
\text { (pCi/g) }\end{array}$ \\
\hline \multicolumn{4}{|c|}{ Radionuclides } \\
\hline Uranium-233/234 & $169^{c}$ & $129^{d}$ & $129^{d}$ \\
\hline Uranium-235 & $17^{\mathrm{c}}$ & $13^{d}$ & $13^{d}$ \\
\hline Uranium-238 & $165^{c}$ & $125^{d}$ & $125^{d}$ \\
\hline Contaminants of Concern & $\begin{array}{l}\text { Soil Cleanup } \\
\text { Level for Direct } \\
\text { Exposure } \\
(\mathrm{mg} / \mathrm{kg})\end{array}$ & $\begin{array}{l}\text { Soil Cleanup } \\
\text { Level for } \\
\text { Groundwater } \\
\text { Protection } \\
\text { (mg/kg) }\end{array}$ & $\begin{array}{l}\text { Soil Cleanup Level } \\
\text { for River } \\
\text { Protection }^{\mathrm{b}} \\
(\mathrm{mg} / \mathrm{kg})\end{array}$ \\
\hline \multicolumn{4}{|c|}{ Nonradionuclides } \\
\hline Arsenic & $58^{e}$ & $N A^{\dagger}$ & $N A^{\dagger}$ \\
\hline Barium & $4,900^{\mathrm{e}}$ & $N A^{f}$ & $N A^{f}$ \\
\hline Cadmium & $139^{e}$ & $N A^{\dagger}$ & $N A^{\dagger}$ \\
\hline
\end{tabular}


Table 1. Summary of Remedial Action Goals - Industrial Land Use. (2 Pages)

\begin{tabular}{|l|c|c|c|}
\hline Contaminants of Concern & $\begin{array}{c}\text { Soil Cleanup } \\
\text { Level for Direct } \\
\text { Exposure } \\
\text { (mg/kg) }\end{array}$ & $\begin{array}{c}\text { Soil Cleanup } \\
\text { Level for } \\
\text { Groundwater } \\
\text { Protection } \\
\text { (mg/kg) }\end{array}$ & $\begin{array}{c}\text { Soil Cleanup Level } \\
\text { for River } \\
\text { Protection } \\
\text { (mg/kg) }\end{array}$ \\
\hline Chromium & \multicolumn{3}{|c|}{ Nonradionuclides (cont.) } \\
\hline Lead & $>1,000,000$ & $\mathrm{NA}^{\mathrm{f}}$ & $\mathrm{NA}^{\mathrm{f}}$ \\
\hline Selenium & 1,000 & $\mathrm{NA}^{\mathrm{f}}$ & $\mathrm{NA}^{\mathrm{f}}$ \\
\hline Silver' & 400 & $5^{\mathrm{g}}$ & $1^{\mathrm{h}}$ \\
\hline Uranium (total) & 400 & 8 & 0.73 \\
\hline
\end{tabular}

${ }^{a}$ Listed values represent a $15 \mathrm{mrem} / \mathrm{yr}$ dose for the industrial exposure scenario.

b Groundwater protection values represent soil concentrations that will be protective of groundwater. River protection values represent soil concentrations that will not cause applicable river cleanup standards to be exceeded as contaminants migrate through the soil column to the river. Listed values are calculated by RESRAD, based on applicable river cleanup standards in the RDR/RAWP (DOE-RL 2004b).

c Direct exposure lookup values for uranium isotopes calculated using secular equilibrium isotopic ratios and the selected soil cleanup level for total uranium under the industrial exposure-scenario ( $350 \mathrm{pCi} / \mathrm{g})$, as provided in the RDR/RAWP (DOE-RL 2004b).

d Soil lookup values for the protection of groundwater and the Columbia River for uranium isotopes calculated using secular equilibrium isotopic ratios and the selected soil cleanup level for total uranium under the industrial exposure-scenario (267 pCi/g), as provided in the RDR/RAWP (DOE-RL 2004b).

e Cleanup limit based on the inhalation exposure pathway per WAC 173-340-750(4)(b)(ii)(a) or (b).

$f$ The RESRAD model predicts that the constituent will not reach groundwater within 1,000 years based on a generic site profile $(4.6 \mathrm{~m}[15 \mathrm{ft}]$ contaminated zone and $6 \mathrm{~m}[19.6 \mathrm{ft}]$ uncontaminated zone).

9 Soil RAG for groundwater protection calculated from WAC 173-303-740(3)(a)(ii)(A), 1996 ("100 times rule") and the MCL (40 CFR 141).

h Soil RAG for river protection calculated from WAC 173-340-740(3)(a)(ii)(A), 1996 ("100 time rule") and a dilution attenuation factor of 2 , using the ambient water quality criteria provided in WAC 173-201A-040, 1995.

i No value is provided for this constituent in the RDR/RAWP (DOE-RL 2004b); values for silver are determined based on WAC 173-340-740, 1996.

j Based on the calculated isotopic distribution of uranium in the 300 Area and cleanup levels of $350 \mathrm{pCi} / \mathrm{g}$ and $267 \mathrm{pCi} / \mathrm{g}$ for total uranium, the corresponding uranium concentration is $505 \mathrm{mg} / \mathrm{kg}$ and $385 \mathrm{mg} / \mathrm{kg}$, respectively ( $\mathrm{BHI} 2002$ ) for the 300-FF-2 Operable Unit sites.

$\mathrm{MCL} \quad=$ maximum contamination level (drinking water standard)

NA $\quad=$ not applicable

RAG = remedial action goal

RDR/RAWP = remedial design report/remedial action work plan

RESRAD = RESidual RADioactivity (dose assessment model)

WAC $\quad=$ Washington Administrative Code

Soil cleanup levels were established in the interim action ROD based on a limited ecological risk assessment. Although not required by the interim action ROD, a comparison against ecological risk screening levels has been made for the site COCs. Screening values were not exceeded for the COCs for this site, with the exception of selenium. Exceedance of screening values does not necessarily indicate the existence of risk to ecological receptors. It is believed that the presence of selenium at this site does not pose a risk to ecological receptors because the statistical concentration of selenium is within the range of natural site background (Ecology 1994). A baseline risk 
assessment for the river corridor portion of the Hanford Site began in 2004, which includes a more complete quantitative ecological risk assessment. That baseline risk assessment will be used as part of the final closeout decision for this site.

\subsection{SITE DESCRIPTION AND SUPPORTING INFORMATION}

The 618-8 waste site is part of the 300-FF-2 Operable Unit in the 300 Area. The site was reportedly located north of the 300 Area, beneath a portion of the 300 Area North Parking Lot (in the vicinity of Washington State Plane coordinates E 593820,

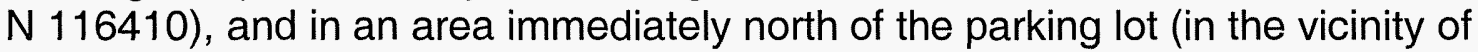
Washington State Plane coordinates E 593820, N 116480) (Figure 1). The burial ground was reported to be a rectangular shaped area approximately $183 \mathrm{~m}(600 \mathrm{ft})$ long

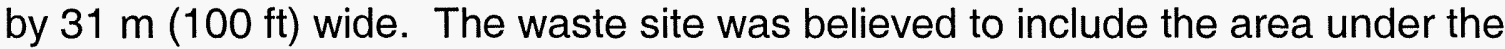
parking lot, because when the North Parking Lot was constructed (sometime in the early 1950s), brass medallions were placed in the asphalt to delineate the presence of an Underground Contaminated Material Area. The waste site was also believed to include the area north of the parking lot because this area was delineated by "post and chain" boundary markers with signs identifying it as an Underground Contaminated Material Area (WCH 2006a).

Information on dates of operation and burial ground inventory are limited. However, it has been speculated that the segment located under the parking lot may have been used in 1943 and 1944 to bury uranium-contaminated waste derived from uranium fuel manufacturing. The area north of the parking lot was speculated to have been used in the mid 1950s to bury uranium-contaminated waste and construction debris from the 1954 remodeling of the 313 Building (WCH 2006a).

Early characterization investigations at the 618-8 Burial Ground included a series of in situ gamma spectral measurements, performed in September 1980. These measurements were performed to determine the nature and extent of radiological contamination at the waste site. Results of the investigation indicated that the radiological contamination was found primarily within established "post and chain" boundaries associated with the area located north of the parking lot. The radiological contamination identified in this investigation consisted exclusively of uranium isotopes, primarily uranium-235 and uranium-238.

Additional characterization included geophysical, ground-penetrating radar (GPR) surveys performed in 1987. These GPR surveys identified two distinct areas containing substantial amounts of buried waste in the areas located north of the parking lot (inside the area previously delineated by the "post and chain" boundaries). The GPR surveys could not identify a traditional trench configuration or evidence of buried waste under the area delineated by the medallions in the parking lot. Subsequent test excavations and trenching performed at the parking lot area did not expose any evidence of buried waste or debris in that area. A total of eight soil samples were collected from soil 
Figure 1. Hanford Site Map and Location of the 618-8 Burial Ground.

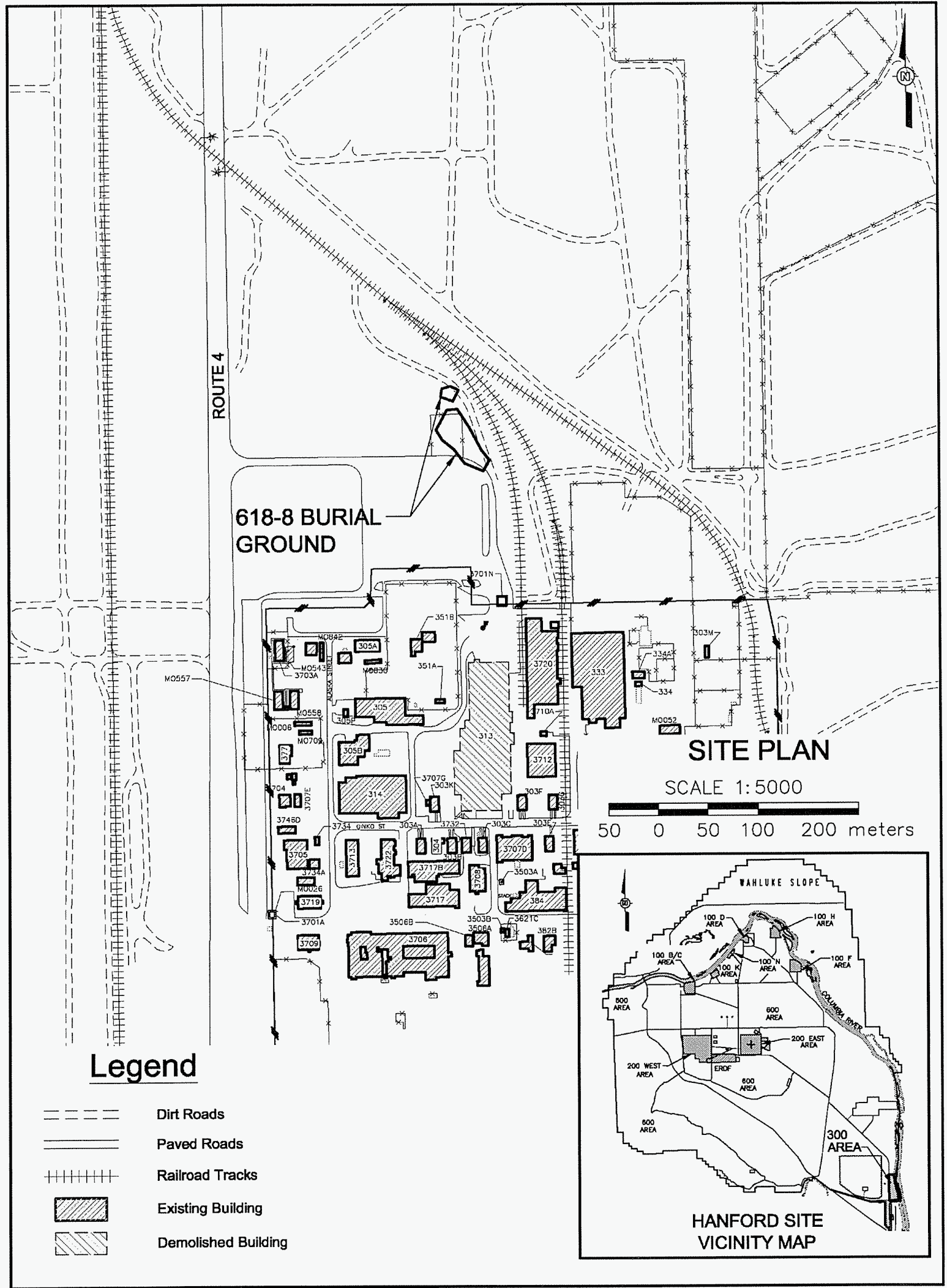


removed during the trenching and test excavations ( $\mathrm{WCH} 2006 \mathrm{~b})$. These samples were analyzed for Resource Conservation and Recovery Act of 1976 metals and a wide range of radionuclides. Analytical results showed all results were either undetected or detected below lookup values. As a result, the area under the parking lot was not excavated further. Results of the parking lot test pit/trenching investigation are documented in $\mathrm{WCH}$ (2006b).

\subsection{REMEDIAL ACTION FIELD ACTIVITIES}

\subsection{EXCAVATION AND DISPOSAL}

Remedial action activities at the 618-8 waste site began on November 1, 2004, and were completed on November 8,2004 . Remediation involved excavation and staging of clean overburden material and removal of contaminated soil to the extent required to satisfy the RAOs and corresponding RAGs. Excavated material consisted of soil and a wide variety of construction-type debris. Some land disposal restricted materials (primarily three metal drums) were identified and separated from the bulk soil and debris during excavation and sorting operations. Sorting and sampling of the excavated soil and debris was performed in a designated staging pile area. The staging pile area used for the 618-8 waste site also supported the 618-2 and 618-3 Burial Ground excavations and will be closed out with the 618-2 waste site. Subsequent to sorting and receipt of sampling results, the "released" material was loaded into ERDF containers and transported to the ERDF for disposal. Segregated land disposal restricted materials were subsequently loaded out and transported to the ERDF under a separate waste profile. In December 2004, load-out operations at the 618-8 Burial Ground staging piles were suspended, due to the discovery of plutonium-contaminated waste at the 618-2 Burial Ground. As part of mitigation actions to stabilize excavated waste and debris from 618-2 Burial Ground, a soil cover was placed on all stockpiled material from the 618-8 Burial Ground.

Load-out of the 618-8 stockpiled material resumed on September 1, 2005, and was completed on September 13, 2005. Approximately 6,462 metric tons (7,125 U.S. tons) of material from the site was removed and disposed at the ERDF. Pre- and postremediation topographic maps are shown in Figures 2 and 3.

There was no indication of bulk liquid waste disposal observed during excavation of the 618-8 waste site.

\subsection{FIELD SCREENING}

Post-excavation radiological surveys of the 618-8 waste site floor were performed in December 2005. The field radiological measurements survey results did not identify any residual radiological contamination above background levels. The radiological survey maps are included as Figures 4 and 5. 
Figure 2. Pre-Remediation Topographic Plan for the Western Portion of the 618-8 Waste Site.

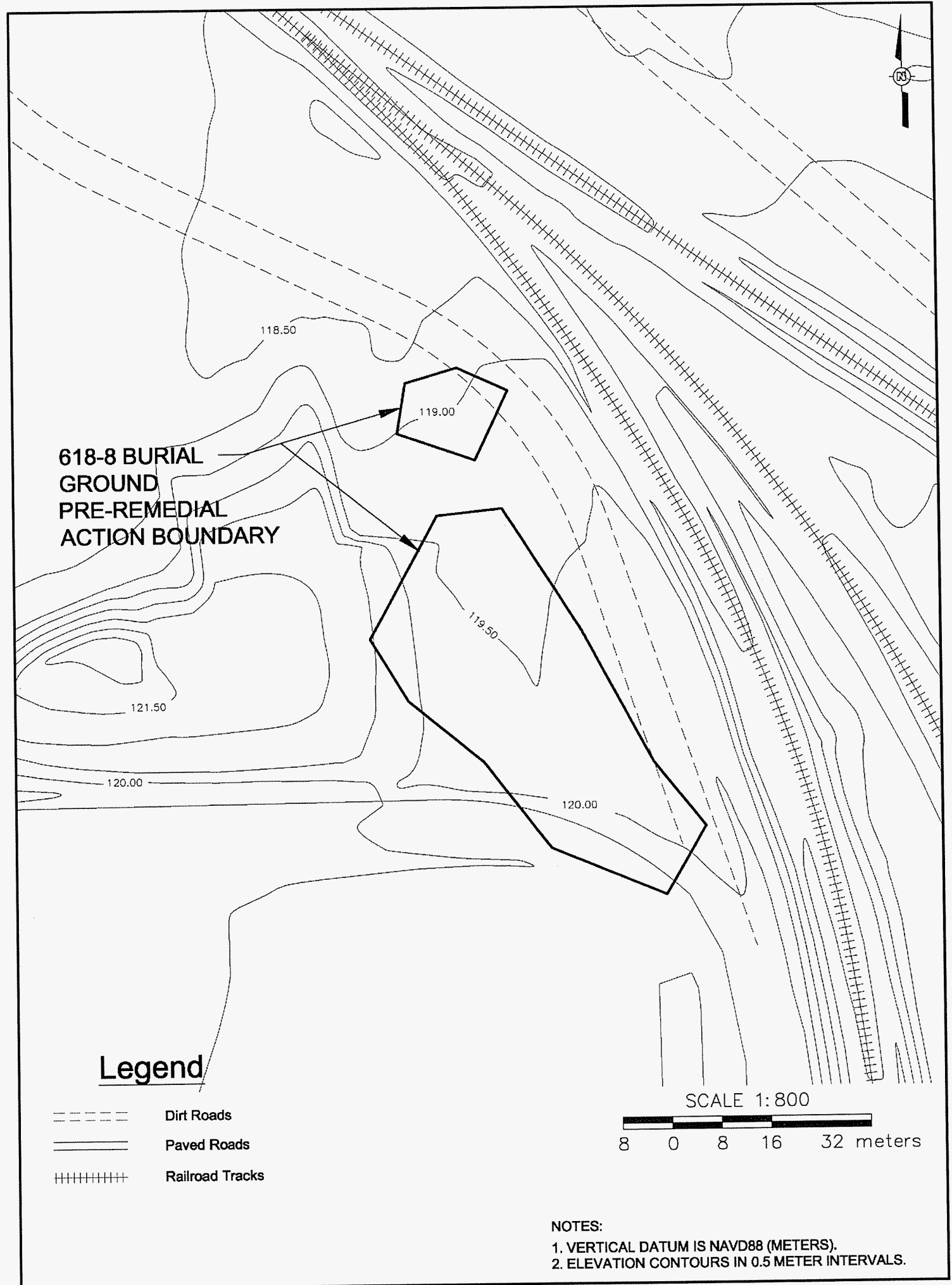


Figure 3. Post-Remediation Topographic Plan for the Western Portion of the 618-8 Waste Site.

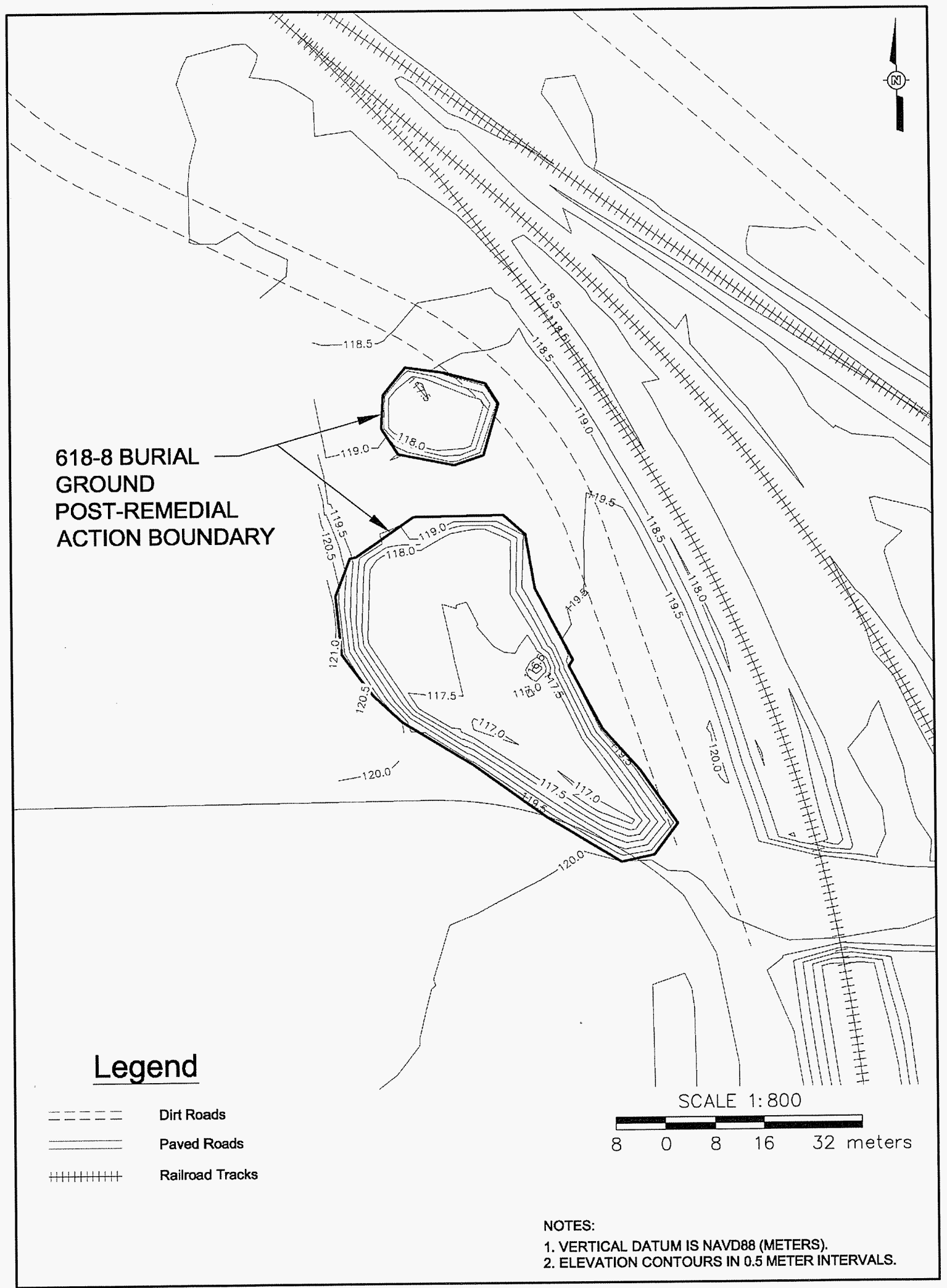




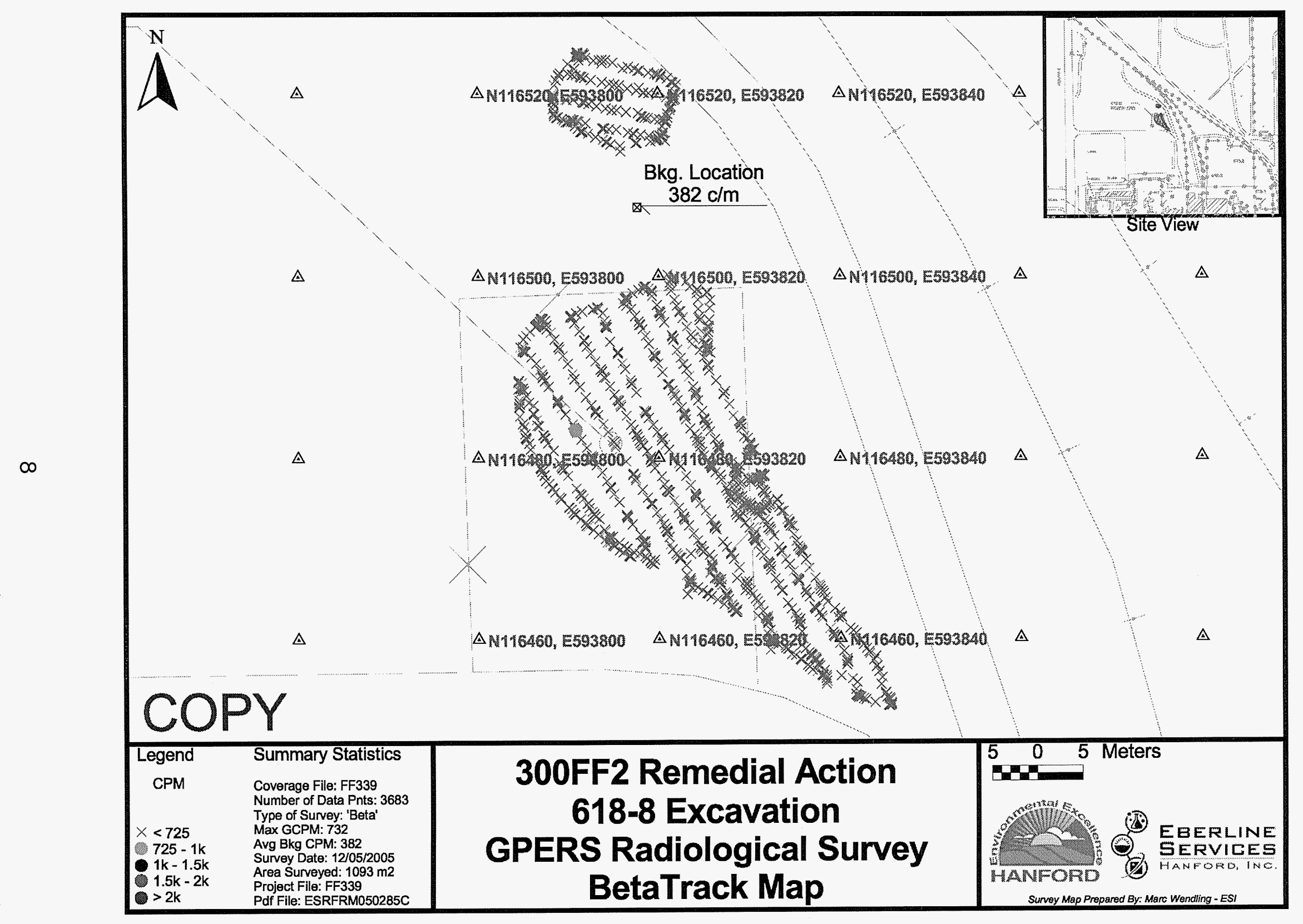

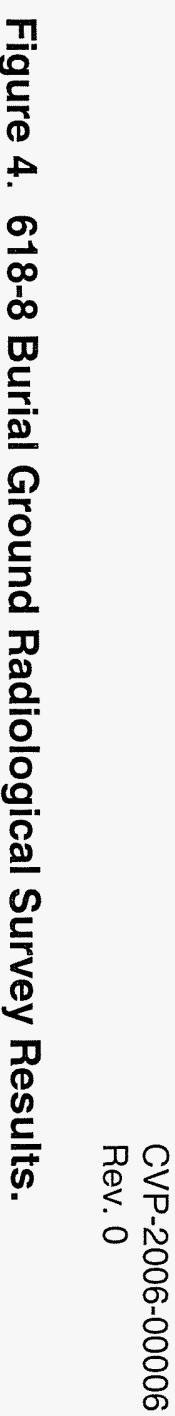




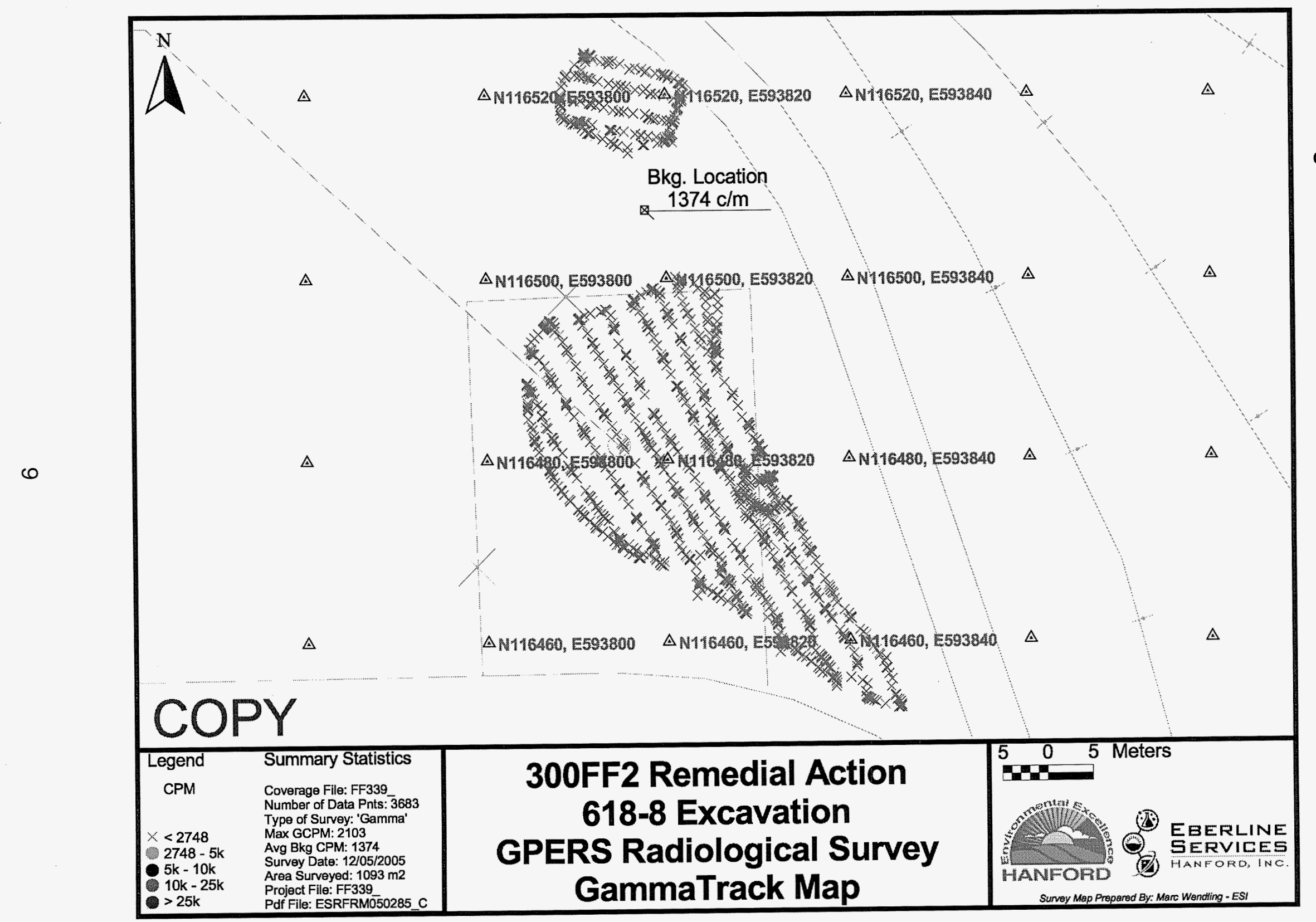

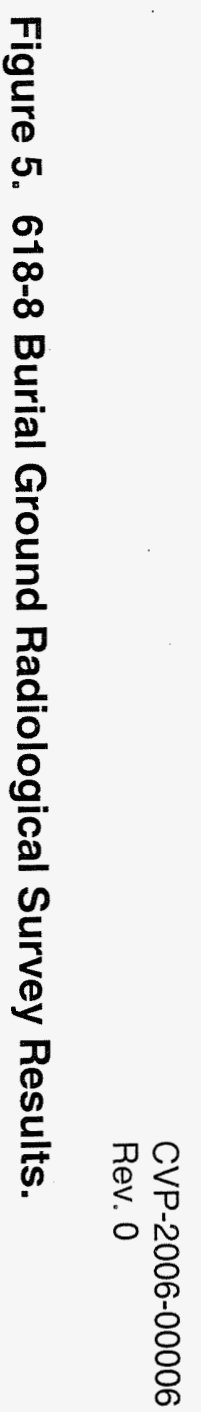




\subsection{CLEANUP VERIFICATION SAMPLING AND ANALYSIS}

Final cleanup verification sampling was conducted on January 31,2006 . The verification samples were submitted to offsite laboratories for analysis using approved U.S. Environmental Protection Agency analytical methods as required per the SAP (DOE-RL 2004a). Each verification sample was composed of a composite sample formed by combining soil collected at the required number of randomly selected locations within each sampling area (excluding the quality assurance/quality control samples).

The 618-8 waste site excavation has only a shallow zone decision unit, as shown on the sample design figure (Appendix $\mathrm{C}$ ), inclusive of the excavation sidewalls and floors. Direct exposure, groundwater protection, and river protection RAGs are all applicable to shallow zone soils (i.e., soils within $4.6 \mathrm{~m}$ [15 ft] of the ground surface). Based on the size of the remediation footprint, the 618-8 shallow zone decision unit is comprised of one decision subunit, divided into four sampling areas (DOE-RL 2004a). All sampling areas were further divided into 16 sampling nodes, each as shown in the sample design methodology and sample location figures presented in the calculation brief in Appendix C. The analytical results for the samples were used for the purposes of statistical calculations, as described in the cleanup verification calculation brief (Appendix C).

\subsection{CLEANUP VERIFICATION DATA EVALUATION}

This section presents the evaluation and modeling of the 618-8 cleanup verification data for comparison with the data quality criteria and RAGs.

\subsection{DATA QUALITY ASSESSMENT PROCESS}

A data quality assessment (DQA) is performed to compare the verification sampling approach and resulting analytical data with the sampling and data quality requirements specified by the project objectives and performance specifications.

The DQA for the 618-8 waste site determined that the data are of the right type, quality, and quantity to support site verification decisions within specified error tolerances. All analytical data were found to be acceptable for decision-making purposes. The evaluation also verified that the sample design was sufficient to support clean site verification. The analytical data are stored in the Environmental Restoration database prior to being transferred to the Hanford Environmental Information System and are summarized in Appendix A. The detailed DQA is presented in Appendix B. 


\subsection{CONTAMINANTS OF CONCERN 95\% UPPER CONFIDENCE LIMIT}

The primary statistical calculation to support cleanup verification is the $95 \%$ upper confidence limit (UCL) on the arithmetic mean of the data. The $95 \%$ UCL values for each COC are computed for the decision unit. Prior to calculating the $95 \%$ UCL, the individual sample results are reviewed and, as appropriate, adjusted per the SAP (DOERL 2004a). This process is summarized below.

\subsubsection{Radionuclides}

For radionuclides, the laboratory-reported value is used in the calculation of the $95 \%$ UCL. In cases where the laboratory does not report a value for data qualified with a "U" (i.e., less than the detection limit), one-half of the minimum detectable activity is used in the calculation of the $95 \% \mathrm{UCL}$.

\subsubsection{Nonradionuclides}

For nonradionuclides, a value equal to one-half the practical quantitation limit is used for data flagged with a " $U$ " (i.e., less than the detection limit) in the calculation of the $95 \%$ $\mathrm{UCL}$, as required by Washington Administrative Code (WAC) 173-340-740[7][g]. If greater than half of the sample results for a given nonradionuclide $\mathrm{COC}$ are below detection, the statistical value is set equal to the maximum concentration detected (i.e., versus computing a $95 \% \mathrm{UCL}$ ).

Statistical calculations for $618-8$ verification data are presented in the $95 \%$ UCL calculation brief (Appendix C), with results shown in Table 2. The columns on the left side of Table 2 are the COCs and the $95 \%$ statistical values before subtraction of background. The third column of Table 2 presents the background, and the last column presents the statistical values adjusted for background, if appropriate, which becomes the cleanup verification data set used for evaluation against RAGs. All of the COCs for the 618-8 site were detected below background in the verification samples, with the exception of selenium, which was detected slightly above background. Individual sample cleanup verification results are presented in Appendix A.

Table 2. Cleanup Verification Data Set. (2 Pages)

\begin{tabular}{|c|c|c|c|}
\hline cocs & $\begin{array}{c}\text { 95\% UCL Statistical } \\
\text { Values }^{\mathrm{a}}\end{array}$ & $\begin{array}{l}\text { Hanford Site } \\
\text { Background }\end{array}$ & $\begin{array}{l}\text { Shallow Zone Cleanup } \\
\text { Verification Data Set }^{\mathrm{b}}\end{array}$ \\
\hline \multicolumn{4}{|c|}{ Radionuclide Concentration ( $\mathrm{pCi} / \mathrm{g}$ ) } \\
\hline Uranium-233/234 & 1.04 & $1.1^{c}$ & $O(<B G)$ \\
\hline Uranium-235 & $0.228 \mathrm{U}$ & $0.11^{c}$ & $0.118 \mathrm{U}$ \\
\hline Uranium-238 & 0.643 & $1.1^{\mathrm{c}}$ & $0(<B G)$ \\
\hline
\end{tabular}


Table 2. Cleanup Verification Data Set. (2 Pages)

\begin{tabular}{|c|c|c|c|}
\hline cocs & $\begin{array}{c}\text { 95\% UCL Statistical } \\
\text { Values }^{\mathrm{a}}\end{array}$ & $\begin{array}{l}\text { Hanford Site } \\
\text { Background }\end{array}$ & $\begin{array}{l}\text { Shallow Zone Cleanup } \\
\text { Verification Data Set }^{\mathrm{b}}\end{array}$ \\
\hline \multicolumn{4}{|c|}{ Nonradionuclide Concentration (mg/kg) } \\
\hline Arsenic & 3.7 & 6.5 & 3.7 \\
\hline Barium & 93.3 & 132 & 93.3 \\
\hline Cadmium & $0.07 \mathrm{U}$ & $0.81^{\mathrm{c}}$ & $0.07 \mathrm{U}$ \\
\hline Chromium & 11.8 & 18.5 & 11.8 \\
\hline Lead & 4.8 & 10.2 & 4.8 \\
\hline Selenium & 0.83 & $0.78^{\mathrm{c}}$ & 0.83 \\
\hline Silver & $0.15 \mathrm{U}$ & 0.73 & $0.15 \mathrm{U}$ \\
\hline Uranium (total) & 1.7 & 3.21 & 1.7 \\
\hline
\end{tabular}

a Laboratory data, including the minimum detectable activity or practical quantitation limit for the individual cleanup verification samples, are included in Appendix A and the 95\% UCL calculation brief in Appendix C.

${ }^{b}$ For shallow zone decision units, background is subtracted only for naturally occurring radionuclides (e.g., uranium).

Nonradionuclide background levels are considered in direct evaluation of the cleanup verification data set.

${ }^{c}$ Hanford Site Background: Part 2, Soil Background for Radionuclides (DOE-RL 1996).

${ }^{d}$ Hanford Site-specific background not available. Value is from Ecology publication 94-11 (Ecology 1994).

$B G=$ background

$U=$ undetected (in all samples)

$\mathrm{COC}=$ contaminant of concern

$\mathrm{UCL}=$ upper confidence limit

\subsection{SITE-SPECIFIC CLEANUP VERIFICATION MODEL}

A site-specific vadose zone model was not developed for the 618-8 waste site. For the statistical cleanup verification data set, all COCs were either undetected, or the statistical values were determined to be below statistical background levels, with the exception of selenium, which was detected slightly above background, as shown in Table 2.

\subsection{RESRAD MODELING}

A site-specific RESidual RADioactivity (RESRAD) model was not developed for the 618-8 waste site, because the statistical values for radionuclides were determined to be below the statistical background levels as reported in Hanford Site Background: Part 2, Soil Background for Radionuclides (DOE-RL 1996).

\subsection{EVALUATION OF REMEDIAL ACTION GOAL ATTAINMENT FOR INDUSTRIAL LAND USE}

This section demonstrates that remedial action at the 618-8 waste site has achieved the applicable RAGs developed to support industrial land use. Sections 5.1, 5.2, and 5.3 address attainment of direct exposure RAGs, groundwater protection RAGs, and Columbia River protection RAGs, respectively. Section 5.4 documents application of the 
WAC 173-340-740(7)(e) three-part test, which is required for nonradionuclide COCs only.

\subsection{DIRECT EXPOSURE SOIL REMEDIAL ACTION GOALS ATTAINED}

\subsubsection{Radionuclides}

5.1.1.1 Direct Comparison to RAGs. Radionuclide COCs were either not detected or detected below background levels for the statistical verification data set at the 618-8 waste site, as shown in Table 2. All applicable RAGs have been met.

5.1.1.2 Radionuclide Risk. Radionuclide COCs were either not detected or detected below background levels for the statistical verification data set at the 618-8 waste site, as shown in Table 2.

\subsubsection{Nonradionuclides}

5.1.2.1 Direct Comparison to RAGs. All nonradionuclide COCs in the statistical verification data set were either not detected or detected below background levels, with the exception of selenium, which was detected slightly above background, as shown in Table 2. Table 3 compares the nonradionuclide cleanup verification statistical values for selenium, presented in Table 2, to the direct exposure RAG presented in Table 1. The statistical value is less than the corresponding RAG.

Table 3. Attainment of Nonradionuclide Direct Exposure Standards - Industrial Land Use.

\begin{tabular}{|c|c|c|c|}
\hline Nonradionuclides & $\begin{array}{c}\text { RAG } \\
(\mathbf{m g} / \mathbf{k g})\end{array}$ & $\begin{array}{c}\text { Shallow Zone } \\
\text { Verification Data Set } \\
\text { Values } \\
(\mathbf{m g} / \mathbf{k g})\end{array}$ & $\begin{array}{c}\text { Direct Exposure } \\
\text { RAG Attained }\end{array}$ \\
\hline Selenium & 17,500 & 0.83 & Yes \\
\hline
\end{tabular}

${ }^{a}$ Criterion is comparison to direct exposure RAG.

$\mathrm{RAG}=$ remedial action goal

5.1.2.2 Noncarcinogenic Hazard Quotient RAG Attained. For noncarcinogenic COCs, WAC 173-340-740(5)(a) and (b) specify the evaluation of the hazard quotient, which is given as daily intake divided by a reference dose. This evaluation is shown in the 95\% UCL calculation brief (Appendix C). The calculated hazard quotient for statistical residual selenium concentrations (the only nonradionuclide $\mathrm{COC}$ detected above background) at the 618-8 waste site is $2.1 \times 10^{-3}$. This value is below the individual and cumulative RAGs (a hazard quotient of 1.0 in both cases).

5.1.2.3 Carcinogenic Risk RAG Attained. For individual nonradionuclide carcinogenic COCs, the WAC 173-340-745(4)(a)(iii) Method C cleanup limits are based 
on an industrial land-use incremental cancer risk of $1 \times 10^{-5}$. The cumulative excess cancer risk for all nonradionuclide carcinogenic COCs must also be less than $1 \times 10^{-5}$ (WAC 173-340). Excess cancer risk was not calculated because the nonradionuclide carcinogenic COCs identified for the 618-8 waste site (arsenic and cadmium) were either not detected or detected below the statistical background levels.

\subsection{GROUNDWATER REMEDIAL ACTION GOALS ATTAINED}

\subsubsection{Radionuclides}

Radionuclide COCs were either not detected or detected below background levels for the statistical verification data set at the 618-8 waste site, as shown in Table 2. Therefore, the groundwater protection RAGs have been attained.

\subsubsection{Nonradionuclides}

All nonradionuclide COCs in the statistical verification data set were either not detected or detected below background levels, with the exception of selenium. Selenium was detected slightly above background, but below the applicable RAGs. Table 4 compares the nonradionuclide cleanup verification statistical values for selenium, presented in Table 2, to the soil RAG for groundwater protection presented in Table 1. Residual concentrations of selenium, the sole nonradionuclide $\mathrm{COC}$ detected above background for the 618-8 waste site, are less than the soil RAG for groundwater protection.

Table 4. Attainment of Nonradionuclide Groundwater and River Protection Standards for the 618-8 Waste Site.

\begin{tabular}{|l|c|c|c|c|}
\hline $\begin{array}{c}\text { Contaminant of } \\
\text { Concern }\end{array}$ & $\begin{array}{c}\text { Cleanup } \\
\text { Verification Data } \\
\text { Set } \\
(\mathbf{m g} / \mathbf{k g})\end{array}$ & $\begin{array}{c}\text { Soil RAG for } \\
\text { Groundwater } \\
\text { Protection } \\
(\mathbf{m g} / \mathbf{k g})\end{array}$ & $\begin{array}{c}\text { Soil RAG for } \\
\text { River } \\
\text { Protection } \\
(\mathbf{m g} / \mathbf{k g})\end{array}$ & $\begin{array}{c}\text { Cleanup Criteria } \\
\text { Attained }^{\mathrm{a}}\end{array}$ \\
\hline Selenium & 0.83 & $5^{\mathrm{b}}$ & $1^{\mathrm{c}}$ & Yes \\
\hline
\end{tabular}

a Criterion is comparison to soil RAGs for groundwater and river protection.

b Soil RAG for groundwater protection calculated from WAC 173-303-740(3)(a)(ii)(A), 1996 ("100 times rule") and the maximum contaminant level (drinking water standard) (40 CFR 141).

c Soil RAG for river protection calculated from WAC 173-340-740(3)(a)(ii)(A), 1996 ("100 time rule") and a dilution attenuation factor of 2 , using the ambient water quality criteria provided in WAC 173-201A-040, 1995. $\mathrm{RAG}=$ remedial action goal

\subsection{COLUMBIA RIVER REMEDIAL ACTION GOALS ATTAINED}

\subsubsection{Radionuclides}

Radionuclide COCs were either not detected or detected below background levels for the statistical verification data set at the 618-8 waste site, as shown in Table 2, therefore, the river protection RAGs have been attained. 


\subsubsection{Nonradionuclides}

All nonradionuclide COCs in the statistical verification data set, with the exception of selenium, were either not detected or detected below background levels and are, therefore, below applicable soil RAGs for protection of the Columbia River. Selenium was detected slightly above background. Residual concentrations of selenium are less than the applicable soil RAG for protection of the Columbia River (Table 4).

\subsection{WAC 173-340 THREE-PART TEST FOR NONRADIONUCLIDES}

Although performed for all nonradionuclide COCs in the $95 \%$ UCL calculation (Appendix C, the WAC 173-340-740(7)(e) three-part test is required only for nonradionuclide statistical verification data sets with detections above background. The three-part test consists of the following criteria: (1) the cleanup verification statistical value must be less than the cleanup level, (2) no single detection within the data set can exceed two times the cleanup criteria, and (3) the percentage of samples in the data set exceeding the cleanup criteria must be less than $10 \%$.

Selenium was the only nonradionuclide detected above background in the statistical verification data set. Table 5 summarizes the results of the WAC 173-340-740[7][e] three-part test for the 618-8 cleanup verification nonradionuclide data set for selenium in comparison to the most restrictive applicable RAG. The table lists the most restrictive RAG (from Table 1), the maximum detected value, the total number of samples collected, and the percentage of samples exceeding the RAG. The final column of the table describes the result of applying the three criteria using the values listed in the preceding columns.

Table 5. Application of the WAC 173-340 Three-Part Test.

\begin{tabular}{|l|c|c|c|c|c|c|}
\hline $\begin{array}{c}\text { Contaminant } \\
\text { of Concern }\end{array}$ & $\begin{array}{c}\text { Most } \\
\text { Restrictive } \\
\text { Applicable } \\
\text { RAG }^{\mathbf{a}}\end{array}$ & $\begin{array}{c}\text { Statistical } \\
\text { Cleanup } \\
\text { Verification } \\
\text { Value } \\
(\mathbf{m g} / \mathbf{k g})^{\mathbf{b}}\end{array}$ & $\begin{array}{c}\text { Maximum } \\
\text { Detected } \\
\text { Cleanup } \\
\text { Verification } \\
\text { Value } \\
(\mathbf{m g} / \mathbf{k g})^{\mathbf{c}}\end{array}$ & $\begin{array}{c}\text { Total } \\
\text { Number } \\
\text { of } \\
\text { Samples }\end{array}$ & $\begin{array}{c}\text { Percentage of } \\
\text { Cleanup } \\
\text { Verification Data } \\
\text { Set Exceeding } \\
\text { RAG }^{\mathbf{e}}\end{array}$ & $\begin{array}{c}\text { Cleanup } \\
\text { Criteria } \\
\text { Attained? }\end{array}$ \\
\hline Selenium & $1^{\mathrm{f}}$ & 0.83 & 0.85 & 4 & 0 & Yes \\
\hline
\end{tabular}

a From Table 1, the most restrictive RAG is the soil RAG for protection of the Columbia River.

b Criterion is statistical value cannot exceed most restrictive applicable RAG.

c Criterion is no single detection can exceed two times the most restrictive applicable RAG.

Total number of samples in the decision unit includes field duplicate samples, which are included in the evaluation as separate samples.

e Criterion is percentage of data set exceeding the most restrictive applicable RAG cannot exceed $10 \%$.

f Soil RAG for river protection calculated from WAC 173-340-740(3)(a)(ii)(A), 1996 ("100 time rule") and a dilution attenuation factor of 2 , using the ambient water quality criteria provided in WAC 173-201A-040, 1995.

$\mathrm{RAG}=$ remedial action goal

WAC $=$ Washington Administrative Code 
CVP-2006-00006

Rev. 0

As demonstrated in Table 5, residual shallow zone concentrations of selenium (the sole nonradionuclide COC exceeding background) at the 618-8 site pass the three-part test in comparison to the most restrictive applicable RAG, therefore, the RAOs for protection of groundwater and the river have been attained.

\subsection{EVALUATION OF REMEDIAL ACTION GOAL ATTAINMENT FOR UNRESTRICTED LAND USE}

The information presented in the previous section demonstrates that the cleanup objectives established in the ROD (EPA 2001) for industrial land use have been achieved. In addition, residual soil concentrations indicated that cleanup levels for more stringent land uses may have been achieved for the 618-8 waste site. The information presented in this section evaluates the remedial action results against cleanup criteria established for unrestricted land use to be implemented at selected sites in the 300-FF-2 Operable Unit through the Explanation of Significant Differences for the 300-FF-2 Operable Unit Record of Decision (ESD) (EPA 2004).

The 300 Area unrestricted land-use scenario is represented by an individual in a rural-residential setting. The exposure pathways considered in estimating dose from radionuclides in soil are inhalation; soil ingestion; ingestion of crops, meat, fish, drinking water, and milk; and external gamma exposure. This individual is conservatively assumed to spend $80 \%$ of his/her lifetime onsite. It is assumed that drinking water and irrigation water are obtained from groundwater, as impacted by the waste site.

Unrestricted land-use cleanup levels for chemicals or nonradionuclides are based on WAC 173-340-740(3), which assumes that the exposure pathway for residual contamination will be from ingestion of contaminated soil. Soil cleanup levels are calculated using the equations provided by WAC 173-340-740(3) for carcinogens and for noncarcinogens. For both carcinogens and noncarcinogens, the calculations assume that a resident with an average body weight $16 \mathrm{~kg}(35 \mathrm{lb})$ over the period of exposure ingests soil at a rate of $200 \mathrm{mg} /$ day $(73 \mathrm{~g} / \mathrm{yr}$ [2.6 oz/yr]), with a frequency of contact of $100 \%$ and a gastrointestinal absorption rate of $100 \%$. For carcinogens, the calculation is based on achieving a lifetime cancer risk goal of 1 in $1,000,000\left(1 \times 10^{-6}\right)$ for an exposure duration of 6 years and a lifetime of 75 years. For noncarcinogens, the calculation is based on achieving a hazard quotient of 1 .

The key assumptions in the 300 Area unrestricted land-use scenario that affect groundwater protection are irrigation at agronomic rates $(76 \mathrm{~cm} / \mathrm{yr}[30 \mathrm{in} . / \mathrm{yr}])$, surface vegetation resulting in an evapotranspiration coefficient of $91 \%$, and inclusion of drinking water ingestion as an exposure pathway. Details of this land-use scenario and associated RAGs are documented in the ESD (EPA 2004). 
A comparison of the 618-8 waste site cleanup verification data set to the cleanup objectives for unrestricted land use as established in the ESD (EPA 2004) is presented in the following sections.

\subsection{DIRECT EXPOSURE SOIL REMEDIAL ACTION GOALS ATTAINED}

\subsubsection{Radionuclides}

6.1.1.1 Direct Comparison to RAGs. Radionuclide COCs were either not detected or detected below background levels for the statistical verification data set at the 618-8 waste site, as shown in Table 2. All applicable RAGs have been met.

6.1.1.2 Radionuclide Risk. Radionuclide COCs were either not detected or detected below background levels for the statistical verification data set at the 618-8 waste site, as shown in Table 2.

\subsubsection{Nonradionuclides}

6.1.2.1 Direct Comparison to RAGs. All nonradionuclide COCs in the statistical verification data set were either not detected or detected below background levels, with the exception of selenium, which was detected slightly above background, as shown in Table 2. Table 6 compares the nonradionuclide cleanup verification statistical values for selenium, presented in Table 2, to the direct exposure RAG presented in Table 1. The statistical value is less than the corresponding RAG.

Table 6. Attainment of Nonradionuclide Direct Exposure Standards - Unrestricted Land Use.

\begin{tabular}{|c|c|c|c|}
\hline Nonradionuclides & $\begin{array}{c}\text { RAG } \\
(\mathbf{m g} / \mathbf{k g})\end{array}$ & $\begin{array}{c}\text { Shallow Zone } \\
\text { Verification Data Set } \\
\text { Values } \\
(\mathbf{m g} / \mathbf{k g})\end{array}$ & $\begin{array}{c}\text { Direct Exposure } \\
\text { RAG Attained } \text { ? }^{\mathrm{a}}\end{array}$ \\
\hline Selenium & 400 & 0.83 & Yes \\
\hline
\end{tabular}

${ }^{\mathrm{a}}$ Criterion is comparison to direct exposure RAG.

$\mathrm{RAG}=$ remedial action goal

6.1.2.2 Noncarcinogenic Hazard Quotient RAG Attained. For noncarcinogenic COCs, WAC 173-340-740(5)(a) and (b) specify the evaluation of the hazard quotient, which is given as daily intake divided by a reference dose. This evaluation is shown in the $95 \%$ UCL calculation brief (Appendix C). The calculated hazard quotient for statistical residual selenium concentrations (the only nonradionuclide $\mathrm{COC}$ detected above background) at the 618-8 waste site is $2.1 \times 10^{-3}$. This value is below the individual and cumulative RAGs (a hazard quotient of 1.0 in both cases). 
6.1.2.3 Carcinogenic Risk RAG Attained. For individual nonradionuclide carcinogenic COCs, the WAC 173-340-745(4)(a)(iii) Method B cleanup limits are based on an unrestricted land-use incremental cancer risk of $1 \times 10^{-6}$. The cumulative excess cancer risk for all nonradionuclide carcinogenic COCs must also be less than $1 \times 10^{-5}$ (WAC 173-340). Excess cancer risk was not calculated because the nonradionuclide carcinogenic COCs identified for the 618-8 waste site (arsenic and cadmium) were either not detected or detected below the statistical background levels.

\subsection{GROUNDWATER REMEDIAL ACTION GOALS ATTAINED}

\subsubsection{Radionuclides}

Radionuclide COCs were either not detected or detected below background levels for the statistical verification data set at the 618-8 waste site, as shown in Table 2. Therefore, the groundwater protection RAGs have been attained.

\subsubsection{Nonradionuclides}

All nonradionuclide COCs in the statistical verification data set were either not detected or detected below background levels, with the exception of selenium. Selenium was detected slightly above background, but below the applicable RAGs. Table 7 compares the nonradionuclide cleanup verification statistical values for selenium, presented in Table 2, to the soil RAG for groundwater protection presented in Table 1. Residual concentrations of selenium, the sole nonradionuclide $\mathrm{COC}$ detected above background for the 618-8 waste site, are less than the soil RAG for groundwater protection.

Table 7. Attainment of Nonradionuclide Groundwater and River Protection Standards for the 618-8 Waste Site.

\begin{tabular}{|l|c|c|c|c|}
\hline COC & $\begin{array}{c}\text { Cleanup } \\
\text { Verification Data } \\
\text { Set } \\
(\mathbf{m g} / \mathbf{k g})\end{array}$ & $\begin{array}{c}\text { Soil RAG for } \\
\text { Groundwater } \\
\text { Protection } \\
(\mathbf{m g} / \mathbf{k g})\end{array}$ & $\begin{array}{c}\text { Soil RAG for } \\
\text { River } \\
\text { Protection } \\
(\mathbf{m g} / \mathbf{k g})\end{array}$ & $\begin{array}{c}\text { Cleanup Criteria } \\
\text { Attained? }\end{array}$ \\
\hline Selenium & 0.83 & $5^{\mathrm{a}}$ & $1^{\mathrm{b}}$ & Yes \\
\hline
\end{tabular}

a Soil RAG for groundwater protection calculated from WAC 173-303-740(3)(a)(ii)(A), 1996 ("100 times rule") and the maximum contaminant level (drinking water standard) (40 CFR 141).

b Soil RAG for river protection calculated from WAC 173-340-740(3)(a)(ii)(A), 1996 ("100 time rule") and a dilution attenuation factor of 2, using the ambient water quality criteria provided in WAC 173-201A-040, 1995.

RAG $=$ remedial action goal 


\subsection{COLUMBIA RIVER REMEDIAL ACTION GOALS ATTAINED}

\subsubsection{Radionuclides}

Radionuclide COCs were either not detected or detected below background levels for the statistical verification data set at the 618-8 waste site, as shown in Table 2, therefore, the river protection RAGs have been attained.

\subsubsection{Nonradionuclides}

All nonradionuclide COCs in the statistical verification data set, with the exception of selenium, were either not detected or detected below background levels and are, therefore, below applicable soil RAGs for protection of the Columbia River. Selenium was detected slightly above background. Residual concentrations of selenium are less than the applicable soil RAG for protection of the Columbia River (Table 7).

\subsection{WAC 173-340 THREE-PART TEST FOR NONRADIONUCLIDES}

Although performed for all nonradionuclide COCs in the 95\% UCL calculation (Appendix C, the WAC 173-340-740(7)(e) three-part test is required only for nonradionuclide statistical verification data sets with detections above background. The three-part test consists of the following criteria: (1) the cleanup verification statistical value must be less than the cleanup level, (2) no single detection within the data set can exceed two times the cleanup criteria, and (3) the percentage of samples in the data set exceeding the cleanup criteria must be less than $10 \%$.

Selenium was the only nonradionuclide detected above background in the statistical verification data set. Table 8 summarizes the results of the WAC 173-340-740[7][e] three-part test for the 618-8 cleanup verification nonradionuclide data set for selenium in comparison to the most restrictive applicable RAG. The table lists the most restrictive RAG (from Table 1), the maximum detected value, the total number of samples collected, and the percentage of samples exceeding the RAG. The final column of the table describes the result of applying the three criteria using the values listed in the preceding columns. 
Table 8. Application of the WAC 173-340 Three-Part Test.

\begin{tabular}{|l|c|c|c|c|c|c|}
\hline $\begin{array}{c}\text { Contaminant } \\
\text { of Concern }\end{array}$ & $\begin{array}{c}\text { Most } \\
\text { Restrictive } \\
\text { Applicable } \\
\text { RAG }^{\mathbf{a}}\end{array}$ & $\begin{array}{c}\text { Statistical } \\
\text { Cleanup } \\
\text { Verification } \\
\text { Value } \\
(\mathbf{m g} / \mathbf{k g})^{\mathbf{b}}\end{array}$ & $\begin{array}{c}\text { Maximum } \\
\text { Detected } \\
\text { Cleanup } \\
\text { Verification } \\
\text { Value } \\
(\mathbf{m g} / \mathbf{k g})^{\mathbf{c}}\end{array}$ & $\begin{array}{c}\text { Total } \\
\text { Number } \\
\text { of } \\
\text { Samples }^{\mathbf{d}}\end{array}$ & $\begin{array}{c}\text { Percentage of } \\
\text { Cleanup } \\
\text { Verification Data } \\
\text { Set Exceeding } \\
\text { RAG }^{\mathbf{e}}\end{array}$ & $\begin{array}{c}\text { Cleanup } \\
\text { Criteria } \\
\text { Attained? }\end{array}$ \\
\hline Selenium & $1^{\mathrm{f}}$ & 0.83 & 0.85 & 4 & 0 & Yes \\
\hline
\end{tabular}

${ }^{a}$ From Table 1, the most restrictive RAG is the soil RAG for protection of the Columbia River.

${ }^{b}$ Criterion is statistical value cannot exceed most restrictive applicable RAG.

c Criterion is no single detection can exceed two times the most restrictive applicable RAG.

d Total number of samples in the decision unit includes field duplicate samples, which are included in the evaluation as separate samples.

e Criterion is percentage of data set exceeding the most restrictive applicable RAG cannot exceed $10 \%$.

f Soil RAG for river protection calculated from WAC 173-340-740(3)(a)(ii)(A), 1996 ("100 time rule") and a dilution attenuation factor of 2, using the ambient water quality criteria provided in WAC 173-201A-040, 1995.

$\mathrm{RAG}=$ remedial action goal

$\mathrm{WAC}=$ Washington Administrative Code

As demonstrated in Table 8, residual shallow zone concentrations of selenium (the sole nonradionuclide COC exceeding background) at the 618-8 site pass the three-part test in comparison to the most restrictive applicable RAG, therefore, the RAOs for protection of groundwater and the river have been attained.

\subsection{STATEMENT OF PROTECTIVENESS}

This CVP demonstrates that remedial action at the 618-8 waste site has achieved the RAOs and corresponding RAGs established for the industrial land-use scenario in the ROD (EPA 2001), EPA (2004), and the RDR/RAWP (DOE-RL 2004b). The contaminated materials from the site have been excavated and disposed at ERDF. The remaining soil at the 618-8 waste site has been sampled, analyzed, and evaluated. Results indicate that the site supports future land uses that can be represented (or bounded) by the industrial land-use scenario and poses no threat to groundwater or the Columbia River. Consequently, the $618-8$ waste site is verified to be remediated in accordance with the ROD.

Because residual soil concentrations indicated that cleanup levels for more stringent land uses may have been achieved for the 618-8 waste site, a supplemental evaluation was performed against the unrestricted land-use RAGs established for the 300 Area in the ESD (EPA 2004). This evaluation demonstrated that the results of verification sampling do not preclude any future uses (as bounded by the rural-residential scenario) and allow unrestricted use of shallow zone soils. In consideration of this and because the site has no deep zone, no institutional controls are required at the 618-8 waste site. 


\subsection{REFERENCES}

40 CFR 141, "National Primary Drinking Water Regulations," Code of Federal Regulations, as amended.

BHI, 2001, Calculation of Total Uranium Activity Corresponding to a Maximum Contaminant Level for Total Uranium of 30 Micrograms per Liter in Groundwater, 0100X-CA-V0038, Rev. 0, Bechtel Hanford, Inc., Richland, Washington.

DOE Order 5400.5, Radiation Protection of the Public and the Environment, U.S. Department of Energy, Washington, D.C.

DOE-RL, 1996, Hanford Site Background: Part 2, Soil Background for Radionuclides, DOE/RL-96-12, Rev. 0, U.S. Department of Energy, Richland Operations Office, Richland, Washington.

DOE-RL, 1998, Tri-Party Agreement Handbook Management Procedures, RL-TPA-90-0001, Guideline Number TPA-MP-14, "Maintenance of the Waste Information Data System (WIDS)," U.S. Department of Energy, Richland Operations Office, Richland, Washington.

DOE-RL, 2004a, 300 Area Sampling and Analysis Plan, DOE/RL-2001-48, Rev. 1, U.S. Department of Energy, Richland Operations Office, Richland, Washington.

DOE-RL, 2004b, Remedial Design Report/Remedial Action Work Plan for the 300 Area, DOE/RL-2001-47, Rev. 1, U.S. Department of Energy, Richland Operations Office, Richland, Washington.

Ecology, EPA, and DOE, 1989, Hanford Federal Facility Agreement and Consent Order, 2 vols., as amended, Washington State Department of Ecology,

U.S. Environmental Protection Agency, and U.S. Department of Energy, Olympia, Washington.

Ecology, 1994, Natural Background Soil Metals Concentrations in Washington State, Publication 94-115, Washington State Department of Ecology, Olympia, Washington.

EPA, 2001, Interim Action Record of Decision for the 300-FF-2 Operable Unit, Hanford Site, Benton County, Washington, U.S. Environmental Protection Agency, Region 10, Seattle, Washington. 
EPA, 2004, Explanation of Significant Differences for the 300-FF-2 Operable Unit Record of Decision, U.S. Environmental Protection Agency, Region 10, Seattle, Washington.

Resource Conservation and Recovery Act of 1976, 42 U.S.C. 6901 et seq.

WAC 173-201A, 1995, "Water Quality Standards for Surface Waters of the State of Washington," Washington Administrative Code.

WAC 173-340, 1996, "Model Toxics Control Act - Cleanup," Washington Administrative Code.

WCH, 2006a, Closeout Plan for the 618-8 Burial Ground, CCN 126068, Washington Closure Hanford, Richland, Washington

WCH, 2006b, Parking Lot Test Pit/Trenching Investigation for the 618-8 Burial Ground, Interoffice Memorandum from L. M. Dittmer to M. J. Haass, CCN 124817, dated June 28, 2006, Washington Closure Hanford, Richland, Washington. 
CVP-2006-00006

Rev. 0

APPENDIX A

SUMMARY OF VERIFICATION SOIL SAMPLING

AND ANALYTICAL RESULTS 
CVP-2006-00006

Rev. 0

A-ii 
Table A-1. 618- 8 Verification Sampling Results.

\begin{tabular}{|c|c|c|c|c|c|c|c|c|c|c|c|c|c|c|}
\hline \multirow{2}{*}{$\begin{array}{c}\text { Sampling } \\
\text { Area }\end{array}$} & \multirow{2}{*}{$\begin{array}{c}\text { HEIS } \\
\text { Number }\end{array}$} & \multirow{2}{*}{$\begin{array}{c}\text { Sample } \\
\text { Date }\end{array}$} & \multicolumn{3}{|c|}{ Silver } & \multicolumn{3}{|c|}{ Arsenic } & \multicolumn{3}{|c|}{ Barium } & \multicolumn{3}{|c|}{ Cadmium } \\
\hline & & & $\mathrm{mg} / \mathrm{kg}$ & $\mathbf{Q}$ & PQL & $\mathrm{mg} / \mathrm{kg}$ & $\mathbf{Q}$ & PQL & $\mathrm{mg} / \mathrm{kg}$ & $\mathbf{Q}$ & PQL & $\mathrm{mg} / \mathrm{kg}$ & $\mathbf{Q}$ & PQL \\
\hline $\mathrm{A} 1$ & $\mathrm{~J} 11271$ & $1 / 31 / 2006$ & 0.15 & $\mathrm{U}$ & 0.15 & 3.4 & & 0.36 & 81.3 & & 0.02 & 0.07 & $U$ & 0.07 \\
\hline $\begin{array}{l}\text { Duplicate } \\
\text { of } \mathrm{J} 11271\end{array}$ & J11272 & $1 / 31 / 2006$ & 0.15 & $U$ & 0.15 & 4.1 & & 0.36 & 79.4 & & 0.02 & 0.07 & $\mathrm{U}$ & 0.07 \\
\hline $\mathrm{A} 2$ & $\mathrm{~J} 11273$ & $1 / 31 / 2006$ & 0.15 & $U$ & 0.15 & 3.8 & & 0.34 & 97.6 & & 0.02 & 0.07 & $\mathrm{U}$ & 0.07 \\
\hline $\mathrm{A} 3$ & $\mathrm{~J} 11274$ & $1 / 31 / 2006$ & 0.15 & $\mathrm{U}$ & 0.15 & 2.4 & & 0.36 & 87.0 & & 0.02 & 0.07 & $\mathrm{U}$ & 0.07 \\
\hline A4 & $\mathrm{J} 11275$ & $1 / 31 / 2006$ & 0.15 & $\mathrm{U}$ & 0.15 & 2.4 & & 0.36 & 69.1 & & 0.02 & 0.07 & $\mathrm{U}$ & 0.07 \\
\hline $\begin{array}{l}\text { Split of } \\
\mathrm{J} 11271\end{array}$ & J11277 & $1 / 31 / 2006$ & 1.1 & $U$ & 1.1 & 3.5 & & 1.1 & 94.9 & & 21.3 & 0.53 & $U$ & 0.53 \\
\hline
\end{tabular}

\begin{tabular}{|c|c|c|c|c|c|c|c|c|c|c|c|c|c|c|}
\hline \multirow{2}{*}{$\begin{array}{c}\text { Sampling } \\
\text { Area }\end{array}$} & \multirow{2}{*}{$\begin{array}{c}\text { HEIS } \\
\text { Number }\end{array}$} & \multirow{2}{*}{$\begin{array}{c}\text { Sample } \\
\text { Date }\end{array}$} & \multicolumn{3}{|c|}{ Chromium } & \multicolumn{3}{|c|}{ Lead } & \multicolumn{3}{|c|}{ Selenium } & \multicolumn{3}{|c|}{ Total Uranium } \\
\hline & & & $\mathrm{mg} / \mathrm{kg}$ & $\mathbf{Q}$ & PQL & $\mathrm{mg} / \mathrm{kg}$ & $Q$ & PQL & $\mathrm{mg} / \mathrm{kg}$ & $\mathbf{Q}$ & PQL & $\mathrm{mg} / \mathrm{kg}$ & $\mathbf{Q}$ & $\mathrm{PQL}$ \\
\hline$A 1$ & $\mathrm{~J} 11271$ & $1 / 31 / 2006$ & 10.4 & & 0.17 & 4.5 & & 0.33 & 0.81 & & 0.38 & 1.28 & & 0.017 \\
\hline $\begin{array}{l}\text { Duplicate } \\
\text { of } \mathrm{J} 11271\end{array}$ & J11272 & $1 / 31 / 2006$ & 11.7 & & 0.17 & 4.2 & & 0.33 & 0.76 & & 0.38 & 1.13 & & 0.017 \\
\hline $\mathrm{A} 2$ & $\mathrm{~J} 11273$ & $1 / 31 / 2006$ & 12.4 & & 0.17 & 5.1 & & 0.32 & 0.51 & & 0.21 & 1.67 & & 0.017 \\
\hline A3 & $\mathrm{J} 11274$ & $1 / 31 / 2006$ & 10.2 & & 0.17 & 4.4 & & 0.33 & 0.85 & & 0.38 & 1.72 & & 0.017 \\
\hline $\mathrm{A} 4$ & $\mathrm{~J} 11275$ & $1 / 31 / 2006$ & 9.4 & & 0.17 & 3.9 & & 0.32 & 0.69 & & 0.38 & 1.35 & & 0.017 \\
\hline $\begin{array}{l}\text { Split of } \\
\mathrm{J} 11271\end{array}$ & $\mathrm{~J} 11277$ & $1 / 31 / 2006$ & 8.3 & & 1.1 & 3.9 & & 1.1 & 0.33 & B & 1.6 & 3.28 & & 0.020 \\
\hline
\end{tabular}

\begin{tabular}{|c|c|c|c|c|c|c|c|c|c|c|c|}
\hline \multirow{2}{*}{$\begin{array}{c}\text { Sampling } \\
\text { Area }\end{array}$} & \multirow{2}{*}{$\begin{array}{c}\text { HEIS } \\
\text { Number }\end{array}$} & \multirow{2}{*}{$\begin{array}{c}\text { Sample } \\
\text { Date }\end{array}$} & \multicolumn{3}{|c|}{ Uranium-233/234 } & \multicolumn{3}{|c|}{ Uranium-235 } & \multicolumn{3}{|c|}{ Uranium-238 } \\
\hline & & & $\mathrm{pCi} / \mathrm{g}$ & $\mathbf{Q}$ & MDA & $\mathrm{pCi} / \mathrm{g}$ & $\overline{\mathbf{Q}}$ & MDA & $\mathrm{pCi} / \mathrm{g}$ & $\bar{Q}$ & $\overline{M D A}$ \\
\hline$\overline{\mathrm{A} 1}$ & $J 11271$ & $1 / 31 / 2006$ & 0.540 & & 0.27 & 0 & $\bar{U}$ & 0.31 & 0.439 & & 0.26 \\
\hline $\begin{array}{l}\text { Duplicate } \\
\text { of } \mathrm{J} 11271\end{array}$ & J11272 & $1 / 31 / 2006$ & 0.736 & & 0.26 & 0.081 & U & 0.31 & 0.401 & & 0.26 \\
\hline $\bar{A} 2$ & $J 11273$ & $1 / 31 / 2006$ & 0.780 & & 0.35 & 0.056 & $\bar{U}$ & 0.42 & 0.734 & & 0.35 \\
\hline $\mathrm{A} 3$ & $J 11274$ & $1 / 31 / 2006$ & 1.19 & & 0.40 & 0.314 & $\mathrm{U}$ & 0.48 & 0.363 & $\mathrm{U}$ & 0.40 \\
\hline A4 & $J 11275$ & $1 / 31 / 2006$ & 0.778 & & 0.25 & 0.078 & $\mathrm{U}$ & 0.30 & 0.518 & & 0.25 \\
\hline $\begin{array}{l}\text { Split of } \\
\text { J11271 }\end{array}$ & J11277 & $1 / 31 / 2006$ & 1.14 & & 0.053 & 0.078 & & 0.030 & 1.10 & & 0.053 \\
\hline
\end{tabular}


CVP-2006-00006

Rev. 0

A-2 
CVP-2006-00006

Rev. 0

APPENDIX B

DATA QUALITY ASSESSMENT

B-i 
CVP-2006-00006

Rev. 0

B-ii 


\section{B1.0 DATA QUALITY ASSESSMENT FOR 618-8 BURIAL GROUND WASTE SITE}

\section{B1.1 OVERVIEW}

The data quality assessment (DQA) completes the data life cycle (i.e., planning, implementation, and assessment) that was initiated by the data quality objectives process. The DQA includes a review of the field logbook information (WCH 2006c) to verify sample location, date, and time. It also involves a scientific and statistical evaluation of the data to determine if they are of the right type, quality, and quantity to support their intended use for closeout decisions.

This DQA was performed in accordance with ENV-1, Environmental Monitoring and Management. Specific data quality objectives for the site are found in the 300 Area Remedial Action Sampling and Analysis Plan (SAP) (DOE-RL 2004a). The DQA is based on the guidelines presented in Guidance for Data Quality Assessment (EPA 2000). Statistical tests used in this DQA were performed as specified in the SAP and the Remedial Design Report/Remedial Action Work Plan for the 300 Area (RDR/RAWP) (DOE-RL 2004b).

Prior to performing statistical tests, the field logbook (WCH 2006c), sample designs (WCH 2006b), and sample analytical data are evaluated. A portion of the cleanup verification sample analytical data is validated for compliance requirements (DOE-RL 2004a). Data evaluation is performed to determine if the laboratory carried out all steps required by the SAP and the laboratory contract governing the conduct of analysis and reporting of the data. This evaluation also examines the available laboratory data to determine if an analyte is present or absent in a sample and the degree of overall uncertainty associated with that determination. Data validation is done in accordance with validation procedures (BHI 2000a, 2000b). After data evaluation and validation, the appropriate statistical analyses are performed on the adjusted raw analytical data (Appendix C) to determine statistical values for each contaminant. The cleanup verification sample analytical data are stored in the Environmental Restoration database prior to being transferred to the Hanford Environmental Information System and are summarized in Appendix A.

\section{B1.2 LABORATORY QUALITY MEASURES}

All verification samples are subject to laboratory-specific quality assurance (QA) requirements, including instrument procurement, maintenance, calibration, and operation. Additional laboratory quality control (QC) checks are performed, as appropriate, for the analytical method at a rate of one per sample delivery group (SDG), or 1 in 20 , whichever is more frequent. Laboratory internal QC checks include the following: 
- Laboratory Contamination. Each analytical batch contains a laboratory (method) blank (material of similar composition as the samples with known/minimal contamination of the analytes of interest) carried through the complete analytical process. The method blank is used to evaluate false-positive results in samples, due to contamination during handling at the laboratory.

- Analytical Accuracy. For most analyses, a known quantity of representative analytes of interest (matrix spike/matrix spike duplicate [MS/MSD]) is added to a separate aliquot of a sample from the analytical batch. The recovery percentage of the added MS is used to evaluate analytical accuracy. For analyses not amenable to MS techniques (e.g., gamma energy analysis) or where analytical recovery is corrected via internal standards (e.g., alpha spectral analyses), accuracy is evaluated from recovery of the QC reference sample (e.g., laboratory control spike or blank spike sample).

- Analytical Precision. Separate aliquots removed from the same sample container (replicate samples) are analyzed for each analytical batch. The replicate sample results (evaluated as relative percent differences [RPDs]) are used to assess analytical precision.

- QC Reference Samples. A QC reference sample is prepared from an independent standard at a concentration other than that used for calibration, but within the calibration range. Reference samples provide an independent check on analytical technique and methodology.

Laboratories are also subject to periodic and random assessments of the laboratory performance, systems, and overall program. These assessments are performed by the Washington Closure Hanford QA group to ensure that the laboratories are performing within laboratory contract requirements.

\section{B1.3 DATA VALIDATION}

After sampling was completed, all of the fixed-base laboratory data from SDG K0204 were submitted for third-party validation to Level C per ENV-1-2.12, "Data Package Validation." Level C validation procedures are specified in Data Validation Procedure for Radiochemical Analysis (BHI 2000b) and Data Validation Procedure for Chemical Analysis (BHI 2000a).

Use of Level C validation procedures was included in the review of the following items, as appropriate, for each analytical method:

- Sample holding times

- Method blanks

- MS/MSD recovery

- Surrogate recovery 
- Sample replicates

- Associated batch laboratory control sample results

- Data package completeness

- Achievement of required (or contractual) detection limits (RDLs).

Data flagged by the validator as estimated (i.e., "J") indicate that the associated concentration is an estimate, but that the data may be used for decision-making purposes. Data flagged as below detection limits (i.e., "U") indicate the contaminant was analyzed for but not detected, and the concentration is below the minimum detectable activity (MDA) for radionuclides or the practical quantitation limit (PQL) (i.e., reporting limit) for nonradionuclides. For nonradionuclides, nondetects are reported at the PQL. For radionuclides, nondetects report the actual value obtained from analysis (positive or negative but less than the MDA) except for limited analyses where no value can be calculated. In these cases, the MDA is reported. This situation is applicable for sample results that are below detection limits. All other validated results are considered to be accurate within the standard errors associated with the methods.

The adequacy of laboratory QA/QC was evaluated for precision, accuracy, completeness, and RDLs pursuant to the SAP (DOE-RL 2004a). The organization performing the data validation reported that, of the data given formal validation, the laboratory met the standards for performance for precision $( \pm 30 \%)$, accuracy $( \pm 30 \%)$, and completeness $(>90 \%)$. Comparison of the RDL with the respective MDA or PQL is discussed in Section B1.4.

The validated SDG K0204 contains six samples (J11271, J11272, J11273, J11274, $\mathrm{J} 11275$, J11276) from the 618-8 Burial Ground. Sample J11276 is the equipment blank and sample $\mathrm{J} 11272$ is a duplicate of sample $\mathrm{J} 11271$. A summary of deficiencies noted during validation follows.

- Radionuclides. The validation DQA noted no major deficiencies.

Total uranium was found in the equipment blank (J11276) at $0.496 \mathrm{mg} / \mathrm{kg}$. The Hanford Site-specific background value for total uranium is $3.21 \mathrm{mg} / \mathrm{kg}$. This result is probably carryover in the analytical equipment but does not represent a significant source of contamination. The field sample data are useable for decision making purposes.

- Nonradionuclides. The validation DQA noted no major deficiencies.

Barium and lead were found in the equipment blank (J11276) at $1.8 \mathrm{mg} / \mathrm{kg}$ and $0.72 \mathrm{mg} / \mathrm{kg}$, respectively.

Third party validation did not qualify any of the data in SDG K0204. 
CVP-2006-00006

Rev. 0

\section{B1.4 LABORATORY DATA EVALUATION}

The following paragraphs include a data evaluation of two verification sample SDGs for the 618-8 Burial Ground, SDG K0204 and SDG J00056. SDG K0204 consists of six total samples (J11271 to J11276) from the 618-8 site: four statistical samples, an equipment blank (J11276) and a field duplicate (J11272). SDG K0204 was also subjected to third party verification, as mentioned above. SDG J00056 consists of one split sample (J11277).

The context for assessing the data includes evaluating the sample data using the statistical methodology from the SAP (DOE-RL 2004a) (included in the calculation briefs in Appendix C) and a comparison of analytical results to the parameters as specified in the SAP. This section summarizes the results of the comparison and presents an evaluation of the affected data.

\section{MAJOR DEFICIENCIES}

Any data anomaly that causes final data to be qualified as rejected ( $R$ flagged) is considered a major deficiency. No major deficiencies were identified in the data.

\section{MINOR DEFICIENCIES}

Sample Holding Times. All of the method-specific holding times were met for all samples in the 618-8 data set.

Method Blanks. The method blank is used to evaluate false-positive results in samples due to contamination during handling at the laboratory.

Radionuclides. In the radionuclide analyses, low-level positive results were observed for uranium-233/234 at $0.035 \mathrm{pCi} / \mathrm{g}$. The Hanford Site-specific background activity for uranium-233/234 is $1.1 \mathrm{pCi} / \mathrm{g}$. Most radiological analytical techniques are counting methods. Due to the nature of this type of analysis, positive, but insignificant, results are not uncommon in the method blank and are not considered contamination.

Nonradionuclides. Barium was detected in the method blank at $0.09 \mathrm{mg} / \mathrm{kg}$. The lowest applicable remedial action goal (RAG) for barium is the river protection RAG at $132 \mathrm{mg} / \mathrm{kg}$. All of the nonradiological method blanks associated with $618-8$ were found acceptable.

MS/MSD Recoveries. Recovery of spiked analytes in the MS/MSD pair is used to evaluate method efficiency and the effect of the matrix on an environmental sample.

Radionuclides. All MS/MSD recoveries for radionuclide analytes were within acceptance criteria. 
Nonradionuclides. In the inductively coupled plasma metals analysis of SDG J00056, the percent recoveries for barium and chromium were $148 \%$ and $128 \%$, respectively. The barium result is outside of the project-specific acceptance criteria of $+/-30 \%$. The chromium result is outside of the laboratory acceptance criteria of $+/-20 \%$, but is within the project-specific acceptance criteria. Both results are attributed to natural heterogeneity in the soil sample used as the matrix. The data are useable for the intended purpose.

RDL Comparison. Reported analytical detection levels for nondetected analytes were compared to the RDLs specified in the SAP (DOE-RL 2005a). When detected results were obtained, evaluation of detection limits was not performed. The data validation and supplemental data evaluation noted any analyses in which the detection limit (MDA or PQL) was above the SAP RDLs for nondetected analytes.

Radionuclides. All of the reported MDAs are sufficiently low for decision-making purposes. All values meet the site cleanup criteria as demonstrated in the calculation briefs (Appendix $\mathrm{C}$ ) and discussed in this cleanup verification package.

Nonradionuclides. All of the reported method detection limits are less than applicable RAGs, and the data are of sufficient quality for decision-making purposes.

Precision and Accuracy Evaluation. Analytical accuracy and precision were evaluated by examination of the RPD of the main, duplicate, and split samples. Only the contaminants of concern (COCs) detected at five times the target detection limit (or greater) are used for data analysis with respect to accuracy and precision.

Radionuclides. RPDs for the radionuclide analytes were not calculated because an evaluation of the data shows none of the analytes were detected in both the main and duplicate (or split) sample at more than five times the target detection limit.

Nonradionuclides. RPDs for the nonradionuclide analytes barium and chromium were calculated for both the duplicate and split samples. In the duplicate sample analysis, both barium and chromium were within acceptance criteria with RPDs of $2.4 \%$ and $12 \%$, respectively. The RPDs for the split sample analysis of barium and chromium were $15 \%$ and $22 \%$, respectively. The acceptance criteria for split sample RPDs is $30 \%$. It was previously discussed that barium and chromium also had high matrix spike recoveries. All of the sample extracts associated with these results were produced using field-collected materials. The natural heterogeneity of field collected soils and materials adds to elevated RPDs. This variability is expected and does not indicate a problem with the analytical system. RPDs of analytes detected at low concentrations (less than five times the detection limit) are also not considered to be indicative of the analytical system performance. The data are useable for decision-making purposes. 


\section{B1.5 FIELD QUALITY ASSURANCE/QUALITY CONTROL}

Field QA/QC measures were used to assess potential sources of error and crosscontamination of soil samples that could bias results. Field QA/QC samples listed in the field logbook (WCH 2006c) are summarized in Table B-1. All main and QA/QC sample results are presented in Appendix $A$.

Table B-1. Summary of Field Quality Control Samples.

\begin{tabular}{|c|c|c|c|}
\hline Equipment Blank & Main Sample & Duplicate & Split \\
\hline $\mathrm{J} 11276$ & $\mathrm{~J} 11271$ & $\mathrm{~J} 11272$ & $\mathrm{~J} 11277$ \\
\hline
\end{tabular}

Field duplicate samples were collected to provide a relative measure of the degree of local heterogeneity in the sampling medium, unlike laboratory duplicates that are used to evaluate precision in the analytical process. The field duplicates are evaluated by computing the RPD of the duplicate samples for each COC. Only analytes with values above five times the detection limits for both the main and duplicate samples are compared. The 95\% upper confidence limit (UCL) calculation brief in Appendix C provides details on duplicate pair evaluation and RPD calculation. The data are suitable for the intended purpose of cleanup verification.

Split samples were collected to provide a relative measure of the degree of variability in the sampling, sample handling, and analytical techniques used by commercial laboratories. The field main and split samples are evaluated by computing the RPD of the split samples for each $\mathrm{COC}$ to determine the usability of the verification data. The U.S. Environmental Protection Agency Contract Laboratory Program duplicate sample comparison methodology, USEPA Contract Laboratory Program National Functional Guidelines for Inorganic Data Review (EPA 1994), is used as an initial test of the data from the splits. Only analytes that had values above five times the contractual RDL for both the main and split sample were compared. The 95\% UCL calculation brief in Appendix $\mathrm{C}$ provides details on split pair RPD calculation. These results are typical of the heterogeneity found in the sample matrices and do not indicate a problem in the analytical systems.

\section{B1.6 SUITABILITY OF DATA}

The DQA for the 618-8 Burial Ground determined that the data are of the right type, quality, and quantity to support site cleanup verification decisions within specified error tolerances. The evaluation verified that the sample design was sufficient for the purpose of clean site verification. All analytical data were found to be acceptable for decision-making purposes. 


\section{B2.0 REFERENCES}

BHI, 2000a, Data Validation Procedure for Chemical Analysis, BHI-01435, Rev. 0, Bechtel Hanford, Inc., Richland, Washington.

BHI, 2000b, Data Validation Procedure for Radiochemical Analysis, BHI-01433, Rev. 0, Bechtel Hanford, Inc., Richland, Washington.

DOE-RL, 2004a, 300 Area Remedial Action Sampling and Analysis Plan, DOE/RL-2001-48, Rev. 1, U.S. Department of Energy, Richland Operations Office, Richland, Washington.

DOE-RL, 2004b, Remedial Design Report/Remedial Action Work Plan for the 300 Area, DOE/RL-2001-47, Rev. 1, U.S. Department of Energy, Richland Operations Office, Richland, Washington.

ENV-1, Environmental Monitoring \& Management, Washington Closure Hanford, Richland, Washington.

EPA, 1994, USEPA Contract Laboratory Program National Functional Guidelines for Inorganic Data Review, EPA 540/R-94/013, U.S. Environmental Protection Agency, Washington, D.C.

EPA, 2000, Guidance for Data Quality Assessment, EPA QA/G-9, QA00 Update, U.S. Environmental Protection Agency, Office of Environmental Information, Washington, D.C.

WCH, 2006a, 618-8 Burial Ground Cleanup Verification 95\% UCL Calculations, Calculation Number 0600X-CA-V0058, Washington Closure Hanford, Richland, Washington.

WCH, 2006b, Closeout Plan for the 618-8 Burial Ground, CCN 126068, Washington Closure Hanford, Richland, Washington.

WCH, 2006c, Remedial Sampling, Logbook EL-1395-11, Washington Closure Hanford, LLC., Richland, Washington. 
CVP-2006-00006

Rev. 0

B-8 
CVP-2006-00006

Rev. 0

APPENDIX C

CALCULATION BRIEF EXCERPTS

C-i 
CVP-2006-00006

Rev. 0

\section{DISCLAIMER FOR CALCULATIONS}

The calculations that are provided in the following appendix have been generated to document compliance with established cleanup levels. These calculations should be used in conjunction with other relevant documents in the administrative record. 


\section{CALCULATION BRIEFS}

The following calculation briefs have been prepared in accordance with ENG-1, Engineering Services, ENG-1-4.5, "Project Calculations," Washington Closure Hanford, Richland, Washington.

618-8 Shallow Zone Sampling Plan, Calculation No. 0300X-CA-V0067, Rev. 0, Washington Closure Hanford, Richland, Washington.

618-8 Burial Ground Cleanup Verification 95\% UCL Calculations, Calculation No. 0600X-CA-V0058, Rev. 0, Washington Closure Hanford, Richland, Washington.

NOTE: The calculation briefs referenced in this appendix are kept in the active Washington Closure Hanford project files and are available upon request. When the project is completed, the files will be stored in a U.S. Department of Energy, Richland Operations Office repository. 
CVP-2006-00006

Rev. 0

C-4 


\section{CALCULATION COVER SHEET}

Project Title:

Area

Discipline

Subject

Computer Program
618-8 Burial Ground Sample Design 300 Area

Environmental Engineering 618-8 Shallow Zone Sampling Plan

Excel
Job No.

14655

The attached calculations have been generated to document compliance with established cleanup levels. These documents should be used in conjuction with other relevent documents in the administrative record.

Committed Calculation $\quad x \quad$ Preliminary $\square \quad$ Superseded $\square \quad$ Voided $\square$

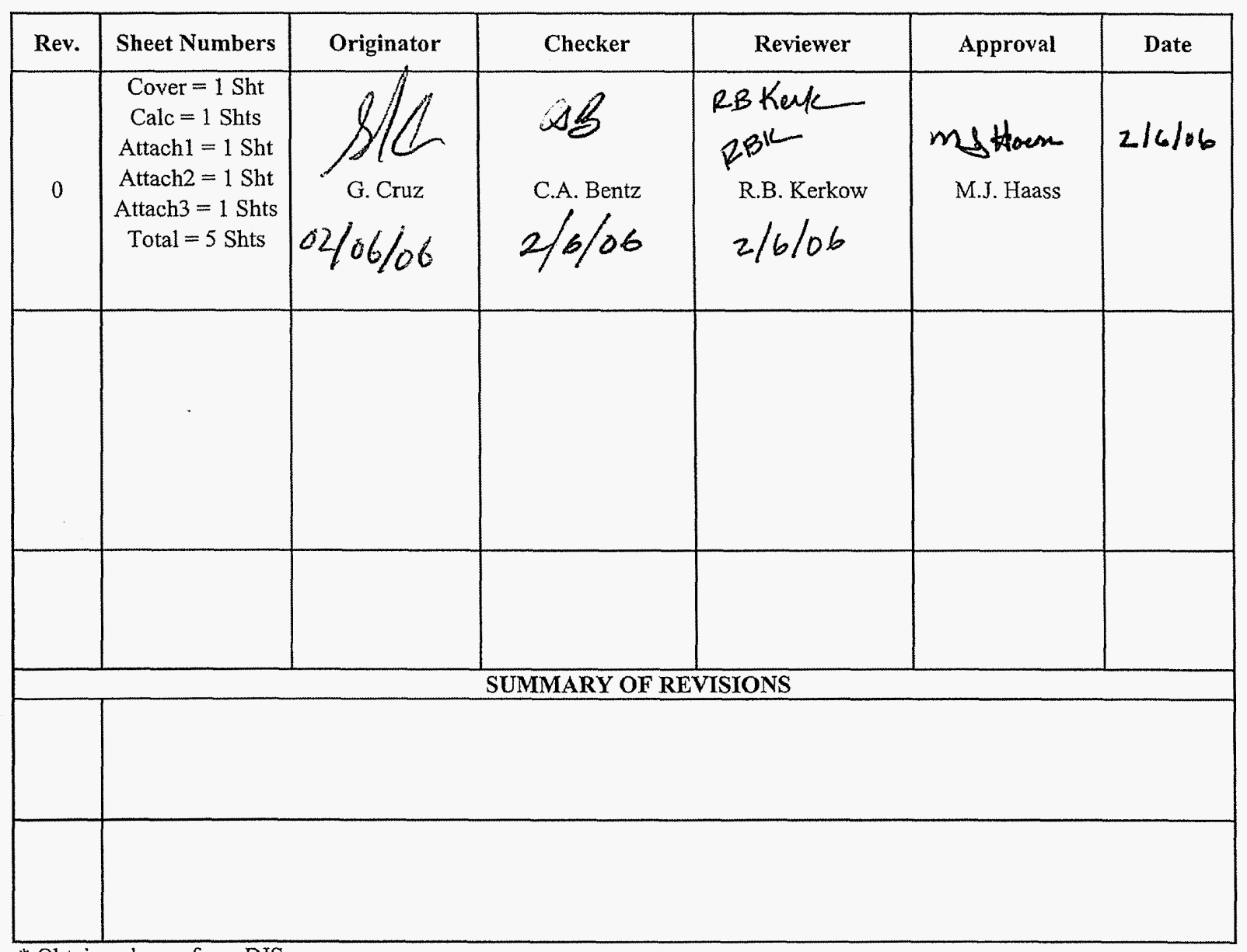

* Obtain calc no. from DIS 
CVP-2006-00006

Rev. 0

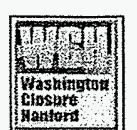

Washington Closure Hanford

Hamtori.

Originator $\mathrm{G}$. Cruz

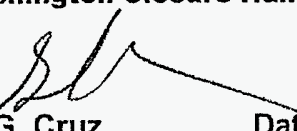

Date $-2 / 2 / 2006$

Project 618-8 Burial Ground Sample Design

Subject 618-8 Shallow Zone Sampling Plan

\section{CALCULATION SHEET}

Calc. No. 0300X-CA-V0067 Rev. No. 0

Job No. 14655 Checked $Q B$ Date $2 / 6 / 06$

Sheet No. 1 of 1

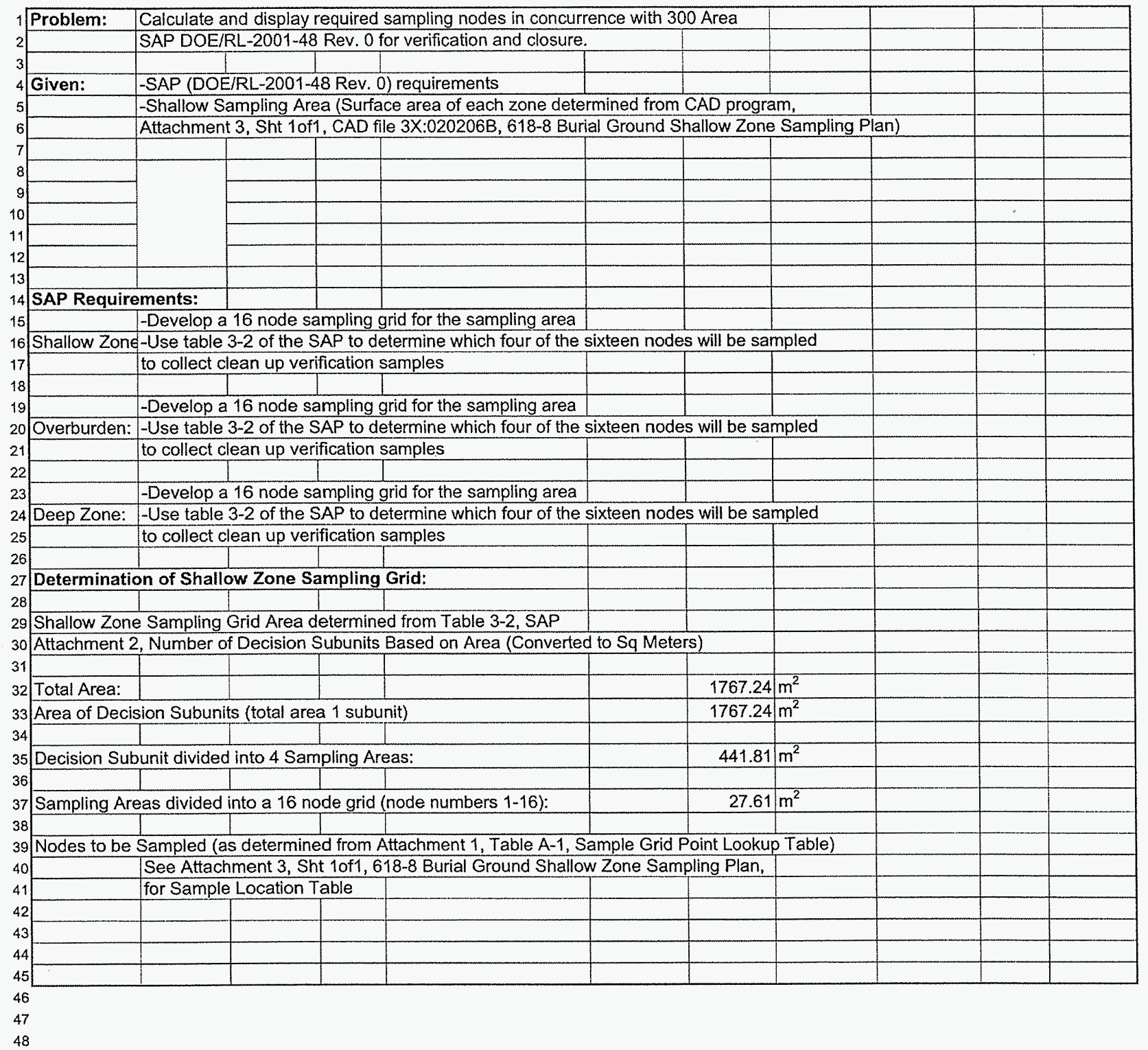


CVP-2006-00006

Rev. 0

\section{Washington Closure Hanford}

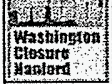

Originator

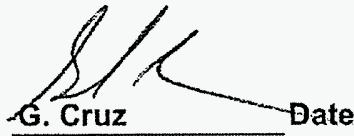

2/2/2006

Calc. No. 0300 X-CA-V0067

Rev. No. 0

Project 618-8 Burial Ground Sample Design Job No. 14655

Checked

Subject 618-8 Shallow Zone Sampling Plan

Sheet No 1 of 1

1 ATTACHMENT 1

${ }_{3}$ Sample Grid Point Lookup Table.

4

\begin{tabular}{|c|c|c|c|c|c|c|c|c|c|c|}
\hline Default Plan & $\begin{array}{c}\text { Sampling } \\
\text { Area } 1\end{array}$ & $\begin{array}{l}\text { Sampling } \\
\text { Area } 2\end{array}$ & $\begin{array}{c}\text { Sampling } \\
\text { Area } 3\end{array}$ & $\begin{array}{l}\text { Sampling } \\
\text { Area } 4\end{array}$ & $\begin{array}{c}\text { Sampling } \\
\text { Area } 5\end{array}$ & $\begin{array}{c}\text { Sampling } \\
\text { Area } 6\end{array}$ & $\begin{array}{c}\text { Sampling } \\
\text { Area } 7\end{array}$ & $\begin{array}{c}\text { Sampling } \\
\text { Area } 8\end{array}$ & $\begin{array}{c}\text { Sampling } \\
\text { Area } 9\end{array}$ & $\begin{array}{c}\text { Sampling } \\
\text { Area } 10\end{array}$ \\
\hline Closeout & 3 & 6 & 1 & 4 & 5 & 1 & 3 & 3 & 4 & 16 \\
\hline Closeout & 4 & 7 & 11 & 3 & 15 & 15 & 5 & 13 & 10 & 10 \\
\hline Closeout & 16 & 3 & 2 & 7 & 7 & 10 & 11 & 4 & 3 & 14 \\
\hline Closeout & 10 & 15 & 4 & 12 & 1 & 13 & 4 & 8 & 16 & 4 \\
\hline Not Sampling & 2 & 14 & 5 & 9 & 13 & 12 & 8 & 2 & 14 & 8 \\
\hline Not Sampling & 13 & 10 & 9 & 13 & 2 & 16 & 1 & 12 & 5 & 3 \\
\hline Not Sampling & 6 & 1 & 10 & 8 & 14 & 4 & 16 & 5 & 8 & 6 \\
\hline Not Sampling & 1 & 9 & 13 & 1 & 10 & 5 & 12 & 1 & 1 & 15 \\
\hline Not Sampling & 9 & 12 & 7 & 5 & 6 & 2 & 6 & 7 & 15 & 9 \\
\hline Not Sampling & 15 & 16 & 15 & 14 & 16 & 6 & 2 & 15 & 11 & 1 \\
\hline Not Sampling & 8 & 13 & 8 & 10 & 12 & 11 & 13 & 14 & 2 & 12 \\
\hline Not Sampling & 5 & 2 & 3 & 11 & 4 & 3 & 9 & 10 & 7 & 11 \\
\hline Not Sampling & 7 & 11 & 14 & 15 & 11 & 14 & 14 & 6 & 13 & 2 \\
\hline Not Sampling & 11 & 4 & 6 & 2 & 9 & 7 & 7 & 11 & 9 & 7 \\
\hline Not Sampling & 12 & 8 & 16 & 16 & 3 & 8 & 15 & 9 & 6 & 13 \\
\hline Not Sampling & 14 & 5 & 12 & 6 & 8 & 9 & 10 & 16 & 12 & 5 \\
\hline
\end{tabular}

25
26
27
28
29
30
31
32
33
34
35
36
37
38
39 
CVP-2006-00006

Rev. 0

Washington Closure Hanford

Hashingtion

Originator G. Cruz

Date $2 / 2 / 2006$

Calc. No. $0300 X-C A-V 0067$

Rev. No. 0

Project 618-8 Burial Ground Sample Design Job No. 14655 Checked

CSB Date 2/6/06

Subject 618-8 Shallow Zone Sampling Plan

Sheet No. 1 of 1

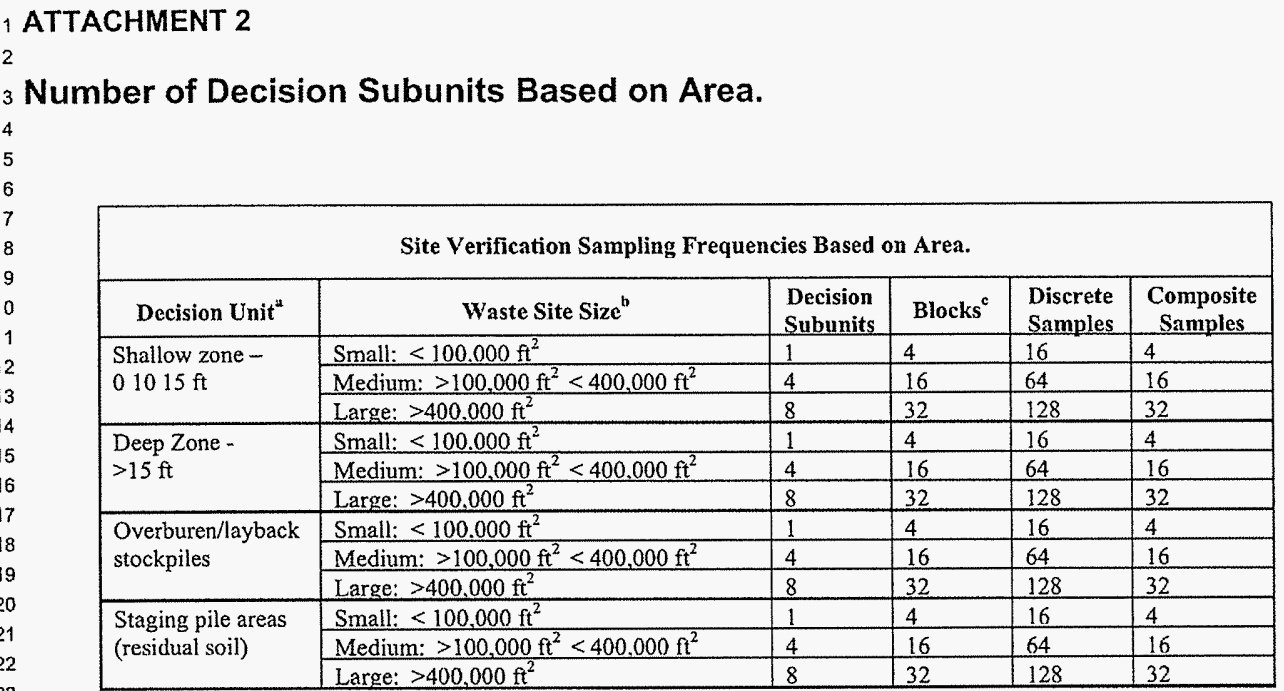

" The shallow zone, decp zone, overburden stockpile, and staging pile areas cach represent single dccision units. The total number of decision units will vary beause individual waste sites may not have a deep zone, overburden stockpile, and/or stnging pile areas.

Arca of exposed surface after cxcavation or area of stockpilc basc (as applicable)

- Decision subunits are divided into four blocks to ensure that random sampling locations are not bunched together in one arca 


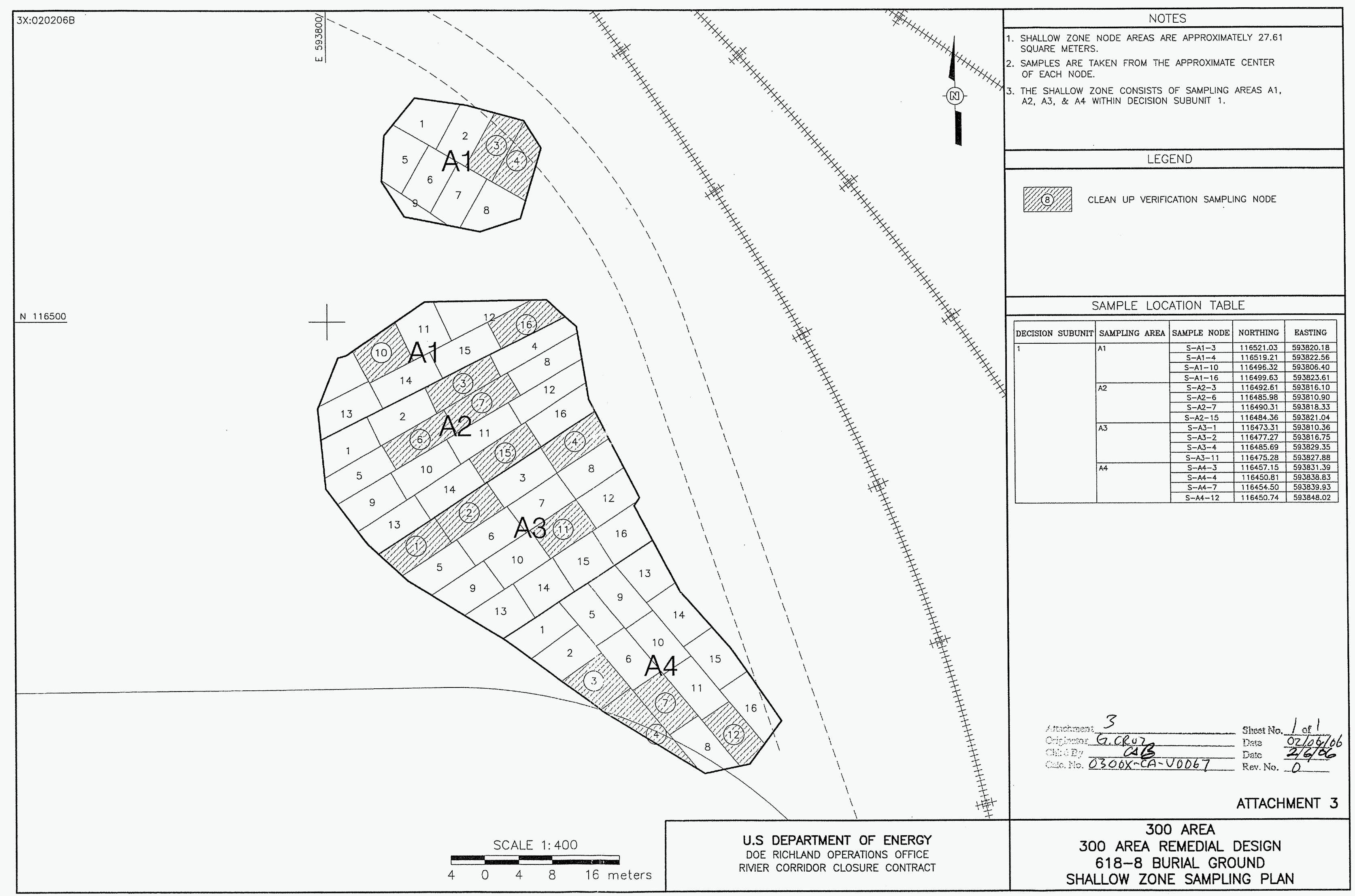




\section{CALCULATION COVER SHEET}

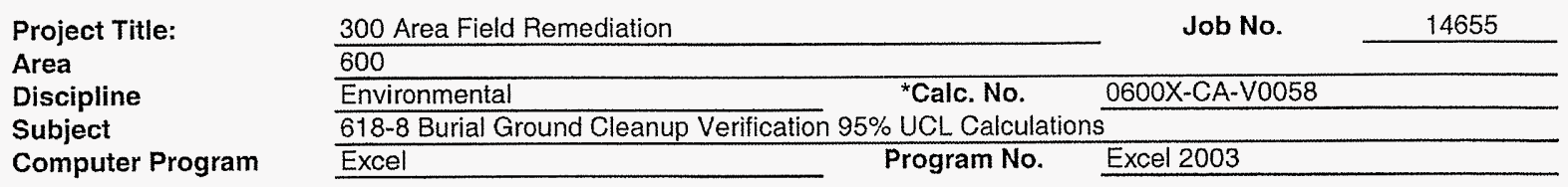

The attached calculations have been generated to document compliance with established cleanup levels. These calculations should be used in conjunction with other relevant documents in the administrative record.

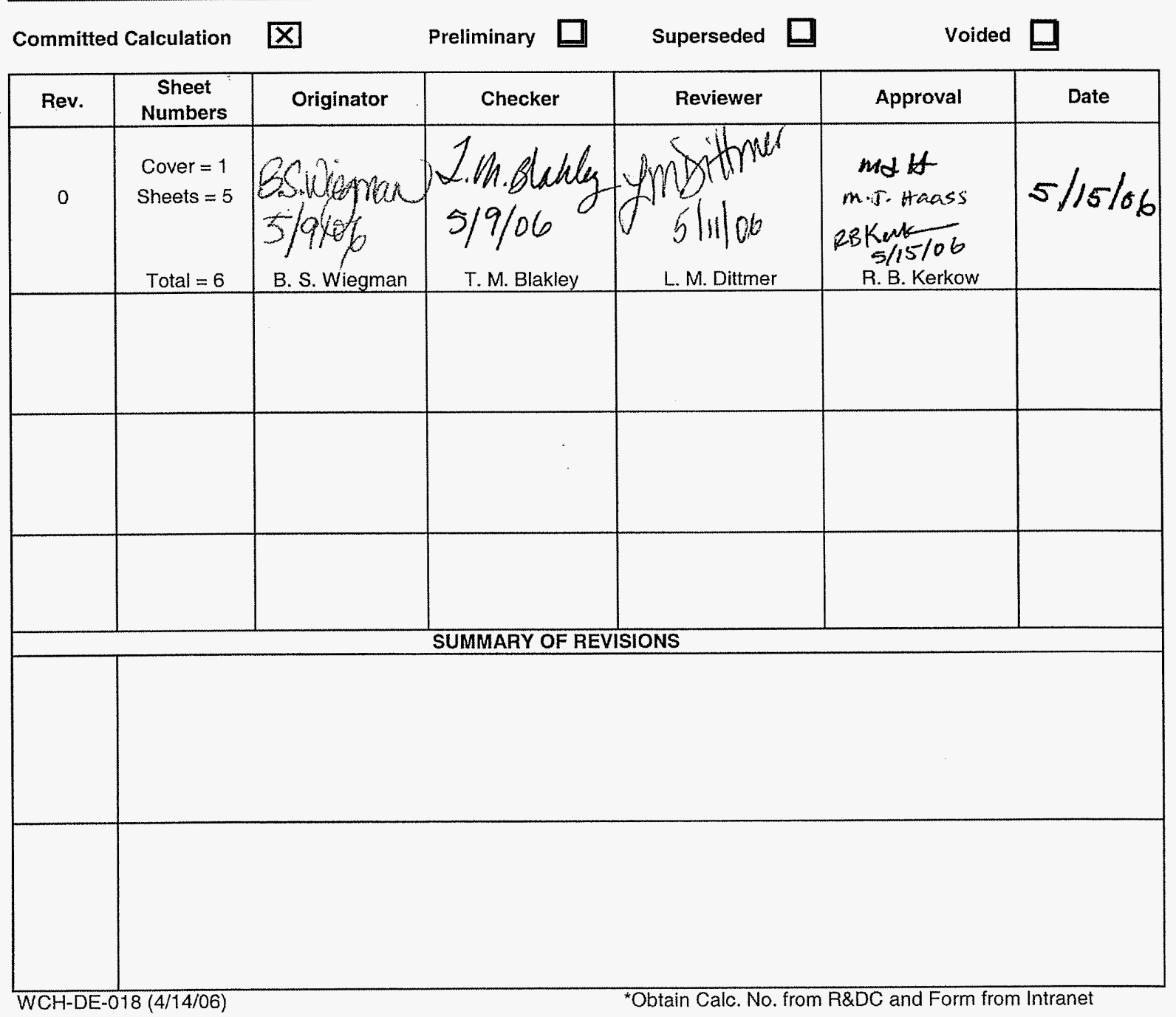


Washington Closure Hanford

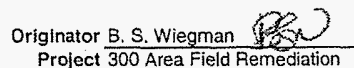

Project 300 Area Field Remediation

Subject 618-8 Burial Ground Cleanup
CALCULATION SHEET Date $05 / 09 / 06$
Job No. 14655
Calc. No. 0600X-CA-V0058

Checked T.M. Blakley $7 \mathrm{~mm}$

Rev. No. $\frac{0}{\text { Date } \frac{05 / 09 / 06}{1 \text { f } 5}}$
Sheet No.

Summary

1 Purpose:

2 Calculate the $95 \%$ upper confidence limit (UCL) to evaluate compliance with cleanup standards for the subject site. Also, calculate the carcinogenic risk for applicable

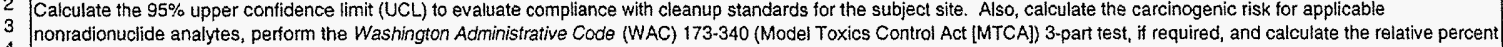
4 difference (RPD) for each contaminant of concern (COC).

6

7 Table of Contents:

Sheets 1 to 2-Calculation Sheet Summary

Sheet 3 - Calculation Sheet Metals

Sheet 4 - Calculation Sheet Radionuclides

Sheet 5 - Calculation Sheet Split-Duplicate Analysis

Given'References:

14 1) Sample Results.

15 2) All lookup values, remedial action goals (RAGs), and background values are taken trom DOE-RL (2001), DOE-RL (2004b), and Ecology (1994) unless stated otherwise.

16 3) DOE-RL, 2001, Hanford Site Background: Part 1, Soil Background for Nonradioactive Analytes, DOE/RL-92-24, Rev. 4, U.S. Department of Energy, Richland Operations

17 Otfice, Fichland, Washington.

18 4) DOE-RL, 2004a, 300 Area Rernedial Action Sampling and Analysis Plan (SAP), DOE/RL,-2001-48, Rev. 1, U.S. Department of Energy, Richland Operations Office, Richland, Washington

20 5) DOE-RL, 2004b, Remedial Design Report/Remedial Action Work Plan for the 300 Area (RDR/RAWP), DOE/RL-2001-47, Rev. 1, U.S. Department of Energy, Fichiand Operations Office, Richland, Washington.

23 6) Ecology, 1992, Statistical Guidance for Ecology Site Managers, Publication \#92-54, Washington State Department of Ecology, Olympia, Washington.

24 7) Ecology, 1993, Statistical Guidance ior Ecology Site Managers, Supplement S-6, Analyzing Site or Background Data with Below-Detection Limit or Below-PQL

25 Values (Censored Data Sets), Publication \#92-54, Washington State Department of Ecology, Olympia, Washington.

26 B) Ecofogy, 1994, Natural Background Soil Metals Concentrations in Washington State, Publication No. 94-115, Washington State Department of Ecology, Olympia,

27 Washington

28 9) Ecology, 1996, Model Toxics Control Act Cleanup Levels and Risk Calculations (CLARC II), Publication \#94-145, Washington State Department of Ecology, Olympia,

29 Washington.

30 10) EPA, 1994, USEPA Contract Laboratory Program National Functional Guidelines for Inorganic Data Review, EPA 540/R-94/013, U.S. Environmental Protection Agency,

Washington, DC.

11) WAC 173-340, 1996, "Model Toxics Control Act-Cleanup," Washington Administrative Code.

35 Solution:

36 Calculation methodology is described in Ecology Pub. \#92-54 (Ecology 1992, 1993), below, and in the RDR/RAWP (DOE-RL 2004b). Use data from the attached worksheets to

37 calculate the $95 \%$ UCL hazard quotients, excess carcinogenic risk, perform the WAC 173-340 3-part test for nonradionuclides, and calculate the RPD for each COC in the primary-

38 duplicate and primary-split sample pairs.

39

40 Calculation Description:

41 The subject calculations were performed on data from soil verification samples from the 618-8 waste site. The data were entered into an EXCEL 2003 spreadsheet and calculations performed by utilizing the built-in spreadsheet functions and/or creating formulae within the cells. The statistical evaluation of data for use in accordance with the RDR/RAWP (DOE 43 RL 2004b) is documented by this calculation. Split and duplicate RPD results are used in evaluation of data quality and are presented in the cleanup verification package (CVP) for 45 this site.

47 Methodology:

48 For nonradioactive analytes with $<50 \%$ of the data below detection limits and all radionuclide analytes, the statistical value calculated to evaluate the effectiveness of cleanup is the $49.95 \%$ UCL For nonradioactive analytes with $>50 \%$ of the data below detection limits, the maximum value for the data set is used instead of the $95 \%$ UCL All nonradionuclide dat 50 reported as being below detection limits are set to $\%$ the dection limit alue for calcultion of the statistics (Ecology 1993). For radionuclide data calculation of the statistics was

51 done on the reported value in cases where the laboratory des not 2 .

53

54 For nonradionuclides, the WAC 173-340 statistical guidance suggests that a fest for distributional form be performed on the data and the $95 \%$ UCL calculated on the appropriate

55 distribution using Ecology software. For nonradionuclide small data sets $(n<10)$ and all radionuclide data sets, the calculations are performed assuming nonparametric distribution,

56 so no test for distribution is performed. For nonracionuclide data sets of ten or greater, distributional testing is done using Ecology's MTCAStat sottware (Ecology 1993).

58 Background is subtracted for applicable radionuclides only. Comparison against background levels for nonradionuclides is included within the CVP.

69 The hazard quotient (for shallow zone nonradionuclide COCs) is determined by dividing the statistical value (derived in this calculation) by the WAC 173-340 non-carcinogenic

61 cleanup limit. The excess nonradionuclide carcinogenic risk is determined by dividing the statistical value by the WAC $173-340$ carcinogenic cleanup limit and then multiplying by $10^{-6}$.

The WAC 173-340 3-part test is performed for nonradionuclide analytes only and determines if:

65 1) the $95 \%$ UCL value exceeds the most stringent cleanup limit for each non-zadionuclide COC,

66 2) greater than $10 \%$ of the raw data exceed the most stringent cleanup limit tor each non-radionuclide $C O C$

68

68 68

70 The RPD is calculated when both the primary value and either the duplicate or split values are above detection limits and are greater than 5 times the target detection limit (TDL)

The TDL is a laboratory detection limit pre-determined for each analytical method, listed in Table II- 1 of the SAP (DOE-RL. 2004a). The RPD calculations use the following formula: RPD $=[\mid M-S / /(M+S) / 2)]^{*} 100$

For quality assurance/quality control (QAOC) split and duplicate RPD calculations, a value less than $+1 \cdot 30 \%$ indicates the data compare favorably. For regulatory splits, a threshold of $35 \%$ is used (EPA 1994). If the APD is greater than 30\% (or $35 \%$ for regulatory split data), further investigation regarding the usability of the data is performed. Additional discussion as necessary is provided in the data quality assessment section of the applicable CVP.

If regulator split comparison is required, an additional parameter is evaluated. A control limit of $+l-2$ times the TDL shall be used if either the main or regulator split value is fess 1 than 5 times the TDL and above detection. In the case where only one result is greater than 5 times the TDL and the other is below, the $+i-2$ times the TDL criteria applies.

82 Therefore, the following calculation is performed as part of the evaluation for these two cases involving regulator split data: difference = main - regutator split. If the difference is

83 greater than $+l-2$ times the TDL, then further investigation regarding the usability of the data is pertormed and presented in the applicable CVP data quality assessment section.

No regulatory split samples were collected for this site. 
CVP-2006-00006

Rev. 0

Washington Closure Hanford

Originator B. S. Wiegman 8 . Project 300 Area Field Remediation Job No. 14655 Job No. 14655

CALCULATION SHEET
Calc. No. 0600X-CA-V0058 Checked T.M. Blakley Zuns
Rev. No. $\frac{0}{05 / 09 / 06}$
Date

Summary (continued)

1 Results:

2 The resulis presented in the summary tables that follow are for use in RESidual RADioactivity dose/risk analysis and the CVP for this site.

Results Summary

\begin{tabular}{|c|c|c|c|}
\hline \multirow{2}{*}{ Analyte } & \multicolumn{2}{|c|}{ Shallow Zone } & \multirow{2}{*}{ Units } \\
\hline & Result & Qualifier & \\
\hline Silver & 0.15 & $\mathrm{U}$ & $\mathrm{mg} / \mathrm{kg}$ \\
\hline Arsenic & 3.7 & & $\mathrm{mg} / \mathrm{kg}$ \\
\hline Barium & 93.3 & & $\mathrm{mg} / \mathrm{kg}$ \\
\hline Cadmium & 0.07 & $U$ & $\mathrm{mg} / \mathrm{kg}$ \\
\hline Chromium & 11.8 & & $\mathrm{mg} / \mathrm{kg}$ \\
\hline Lead & 4.8 & & $\mathrm{mg} / \mathrm{kg}$ \\
\hline Selenium & 0.83 & & $\mathrm{mg} / \mathrm{kg}$ \\
\hline Uranium-233/234 & $0(<B G)$ & & $\mathrm{pCi} / \mathrm{g}$ \\
\hline Uranium-235 & 0.118 & $\mathrm{U}$ & $\mathrm{pCi} / \mathrm{g}$ \\
\hline Uranium-238 & $0(<B G)$ & & $\mathrm{pCi} / \mathrm{g}$ \\
\hline Total Uranium & 1.7 & & $\mathrm{mg} / \mathrm{kg}$ \\
\hline
\end{tabular}

1.7

WAC 173-340 Evaluation

20 3.Pant Test:

$2195 \%$ UCL > Cleanup Limit? NO

$22>10 \%$ above Cleanup Limit? NO

23 Any sample $>2 x$ Cleanup Limit? NO

24

25 Risk Estimate:

26 Nonrad noncarcinogenic index sum: 2.1E-03

27 Nonrad carcinogenic risk:

28

27

29 Relative Percent Difference Results* QA/QC Analysis

$3 0 \longdiv { } \begin{array} { c | c } { \hline } \\ { \text { Analyte } } \end{array}$

\begin{tabular}{l|l|c|c|}
\cline { 2 - 4 } 31 & \multicolumn{1}{|c|}{ Analyte } & $\begin{array}{c}\text { Duplicate } \\
\text { Analysis** }\end{array}$ & $\begin{array}{c}\text { Split } \\
\text { Analysis }\end{array}$ \\
\cline { 2 - 4 } 32 & Silver & & \\
33 & Arsenic & & \\
34 & Barium & $2.4 \%$ & $15 \%$ \\
35 & Cadmium & & \\
36 & Chromium & $12 \%$ & $22 \%$ \\
37 & Lead & & \\
\hline 38 & Selenium & & \\
39 & Uranium-233/234 & & \\
40 & Uranium-235 & & \\
41 & Uranium-238 & \\
\hline
\end{tabular}

42 "A blank cell indicates that RPD evaluation was not required

43 "The significance of the reported RPD values is addressed within the Data Quality Assessment for the CVP for this site.

$44 \mathrm{QAQC}=$ quality assurancelquality control

$45 \mathrm{RPD}=$ relative percent difference

$46 \mathrm{U}=$ undetected 
CVP-2006-00006

Rev. 0

C-14 
Washington Closure Hanford

Originator B. S. Wiegman 8 SON

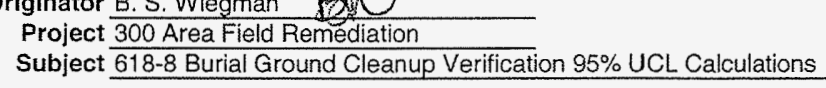

Date $05 / 09 / 06$
Job No..$\underline{14655}$

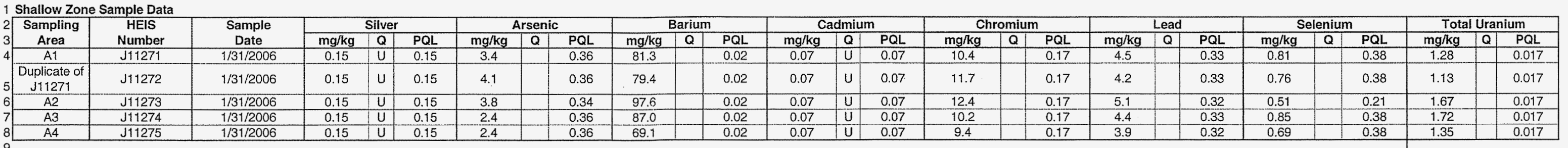

\section{Statistical Computation Input Data}

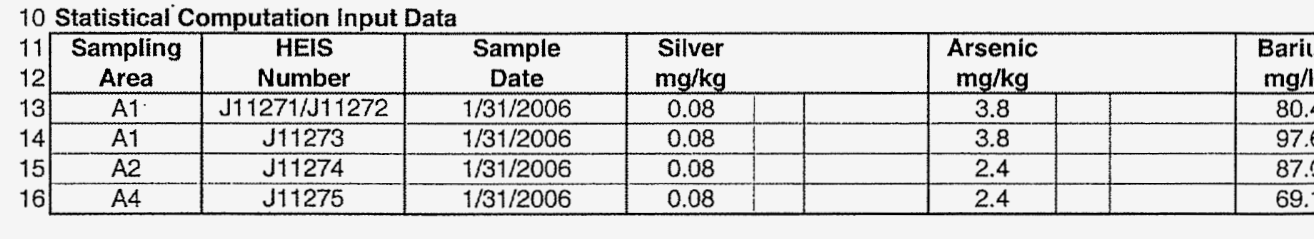

\begin{tabular}{|l|l|l}
$\begin{array}{c}\text { Bariuin } \\
\mathrm{mg} / \mathrm{kg}\end{array}$ & $\begin{array}{c}\text { Cadmium } \\
\mathrm{mg} / \mathrm{kg}\end{array}$ \\
\hline 80.4 & & 0.04 \\
\hline 076 & & 0.04 \\
\hline
\end{tabular}

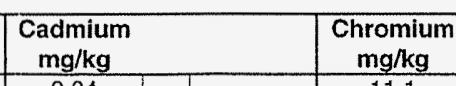

Chromium
$\mathrm{mg} / \mathrm{kg}$
11.1
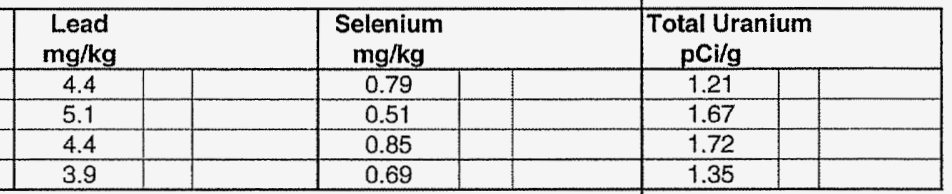

17 Statistical Computations

\begin{tabular}{|c|c|c|c|c|c|c|c|c|c|c|c|c|c|c|c|c|c|}
\hline & & Silver & & Arsenic & & Barlumi & & Cadmium & & Chromium & & Lead & & Selenium & & Total Urani & \\
\hline & & $\begin{array}{l}\text { Small data } \\
\text { nonoarametric }\end{array}$ & $\begin{array}{l}\text { set. Use } \\
\text { ric - rstatisic. }\end{array}$ & $\begin{array}{c}\text { Small } \\
\text { nonoparam }\end{array}$ & $\begin{array}{l}\text { ata set. Use } \\
\text { etrit z-staistic. }\end{array}$ & $\begin{array}{c}\text { Small da } \\
\text { nonparime } \\
\end{array}$ & $\begin{array}{l}\text { atata set. Use } \\
\text { entric }\end{array}$ & \begin{tabular}{|c} 
Small data se \\
nonparametric
\end{tabular} & $\begin{array}{l}\text { set. Use } \\
\text { :z-statistic. }\end{array}$ & $\begin{array}{r}\text { Small da } \\
\text { nonnarame }\end{array}$ & $\begin{array}{l}\text { set. Use } \\
z \text { s-staistic. }\end{array}$ & $\begin{array}{c}\text { Small da } \\
\text { nonparame }\end{array}$ & $\begin{array}{l}\text { ata set. Use } \\
\text { tetic z-statisic. }\end{array}$ & $\begin{array}{l}\text { Small dat } \\
\text { nonparame }\end{array}$ & $\begin{array}{l}\text { ta set. Use } \\
\text { tric } \text { - Statistic. }\end{array}$ & $\begin{array}{c}\text { Small da } \\
\text { nonparame }\end{array}$ & $\begin{array}{l}\text { tita set. Use } \\
\text { tritic z-statistic. }\end{array}$ \\
\hline & $95 \%$ UCL value based or & 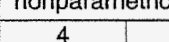 & & \begin{tabular}{|l|l|l|l|l} 
nonparam \\
4
\end{tabular} & & \begin{tabular}{|l|l} 
nompartime \\
4
\end{tabular} & & \begin{tabular}{|l|} 
nomparameiric \\
4
\end{tabular} & & 4 & & \begin{tabular}{|l|l|} 
& nonparame \\
\end{tabular} & & & & 4 & \\
\hline & $\%<$ Detection limit & $\frac{4}{100 \%}$ & & $0 \%$ & & $0 \%$ & & $100 \%$ & & $0 \%$ & & $0 \%$ & & $0 \%$ & & $0 \%$ & \\
\hline & mean & 0.08 & & 3.1 & & 83.5 & & 0.04 & & $\frac{10.8}{1.2}$ & & 4.4 & & 0.7 & & 1.5 & \\
\hline & $\begin{array}{l}\text { st. dev. } \\
\text { Z-s-tatitsic }\end{array}$ & $\frac{0.00}{1645}$ & & $\frac{0.79}{1.45}$ & & $\frac{11.9}{1645}$ & & $\frac{0.00}{1645}$ & & $\frac{1.3}{1.645}$ & & $\frac{0.5}{1.645}$ & & $\frac{0.15}{1645}$ & & $\frac{0.249}{1.645}$ & \\
\hline & $\begin{array}{l}95 \% \text { UCL on mean } \\
\end{array}$ & & & & & $\frac{1.645}{93.3}$ & & $\frac{7.045}{0.04}$ & & $\frac{7.045}{11.8}$ & & $\frac{1.040}{4.8}$ & & & & & \\
\hline & & \begin{tabular}{l|l}
0.00 & $\mathrm{U}$ \\
0.15 & $\mathrm{u}$
\end{tabular} & & $\frac{.1 .1}{4.1}$ & & -97.6 & & 0.0 & & & & & & 0.85 & & & \\
\hline & Statistical value & $\begin{array}{lll}0.15 & \mathrm{U} \\
\end{array}$ & & 3.7 & 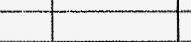 & 93.3 & & \begin{tabular}{l|l}
0.07 & $u$ \\
\end{tabular} & & 11.8 & & 4.8 & & 0.83 & & 1.69 & \\
\hline & $\begin{array}{c}\text { Background } \\
\text { statictical }\end{array}$ & $\begin{array}{l}0.73 \\
015\end{array}$ & & 6.5 & 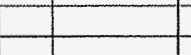 & 132 & & \begin{tabular}{l|l}
0.81 & \\
0.07 & 4 \\
\end{tabular} & & $\frac{18.5}{11.8}$ & & 10 & & $\begin{array}{l}0.78 \\
0.83\end{array}$ & & $\frac{3.21}{1.69}$ & \\
\hline & $\begin{array}{l}\text { Most Stringent Cleanup Limit for } \\
\text { nonradionuclide and RAG type }\end{array}$ & 0.73 & $\begin{array}{l}\text { BG/River } \\
\text { Protection }\end{array}$ & 20 & DC & 1600 & DC & 13.9 & DC & 120000 & DC & 353 & DC & 1 & $\begin{array}{c}\text { River } \\
\text { Protection }\end{array}$ & 53 & GW \\
\hline & WAC 173-340 3-PART Test & & & & & & & & & & & & & & & & \\
\hline & $95 \%<$ & NO & & $\frac{\text { NO }}{\text { NO }}$ & & $\frac{\text { NO }}{\text { NO }}$ & & $\frac{\text { NO }}{\text { NO }}$ & & $\frac{\text { NO }}{\text { NO }}$ & & $\frac{\text { NO }}{\text { NO }}$ & & $\frac{\text { NO }}{\text { NO }}$ & & $\frac{\mathrm{NO}}{\mathrm{NO}}$ & \\
\hline & $\begin{array}{l}>10 \% \text { above Cleanup Limit? } \\
\text { Any sample } 2 \times \text { Cleanup Limit? }\end{array}$ & NO & & NO & & NO & & NO & & NO & & NO & & $\mathrm{NC}$ & & 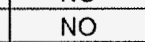 & \\
\hline & EXCESS RISK EVALUATI & 100 & & & & 5600 & & & & 120000 & & 353 & & & & 240 & \\
\hline & $\begin{array}{l}\text { WAC 173-340 Non-Carcinogenic } \\
\text { Hazard quotient for each nonrad }\end{array}$ & & & $\frac{24}{0}$ & & 0 & & 0 & & 0 & & 0 & & $\frac{400}{2.1 \mathrm{E}-03}$ & & $\frac{240}{0}$ & \\
\hline & WAC 173-340 Carcinogenic Cleanup: & NA & & 0.7 & & $\mathrm{NA}$ & & 13.9 & & $\mathrm{NA}$ & & $\mathrm{NA}$ & & NA & & $\mathrm{NA}$ & \\
\hline & Risk for each carcinogenic nonradionuclide: & 0 & & 0 & & 0 & & & & 0 & & 0 & & 0 & & 0 & \\
\hline & $\begin{array}{l}\text { WAC 173-340 3-Part-Test } \\
\text { Compliance? } \\
\text { Nonrad noncarcinogenic } \\
\text { index sum: }\end{array}$ & $\begin{array}{l}\text { Because all sil } \\
\text { are below bac } \\
(0.73 \mathrm{mg} / \mathrm{kg}) \text {, ca } \\
\text { excess risk is } \mathrm{n}\end{array}$ & $\begin{array}{l}\text { silver values } \\
\text { background } \\
\text { calcualtion of } \\
\text { notut required. }\end{array}$ & $\begin{array}{l}\text { Because a } \\
\text { are below } \\
\text { mg/kg, } \\
\text { excess risk }\end{array}$ & $\begin{array}{l}\| 1 \text { arsenic values } \\
\text { background }(6.5 \\
\text { calcualtion of } \\
\text { ris not required. }\end{array}$ & $\begin{array}{l}\text { Because all } \\
\text { are below.bo } \\
\text { mg/kg), } \\
\text { excess risk }\end{array}$ & $\begin{array}{l}\text { all barium values } \\
\text { background (132 } \\
\text { calcualtion of } \\
\mathrm{k} \text { is not required. }\end{array}$ & $\begin{array}{r}\text { Because all c } \\
\text { values are } \\
\text { backround } 0 \\
\text { calcualtion of ex } \\
\text { not ex equi }\end{array}$ & $\begin{array}{l}\text { licadmium } \\
\text { re below } \\
\text { o.81 mglkg), } \\
\text { excess risk is } \\
\text { encest. }\end{array}$ & $\begin{array}{r}\text { Because } \\
\text { values } \\
\text { backgroun } \\
\text { calcualtion } \\
\text { not r }\end{array}$ & 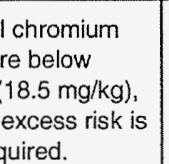 & 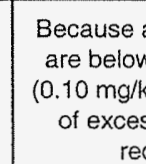 & $\begin{array}{l}\text { all lead values } \\
\text { ow background } \\
\text { likg), calcuattition } \\
\text { ess risk is not } \\
\text { equired. }\end{array}$ & $\begin{array}{l}\text { Because alls } \\
\text { are below ba } \\
\text { migk, } \\
\text { excess risk }\end{array}$ & $\begin{array}{l}\text { selenium values } \\
\text { ckground }(0.78 \\
\text { alcualtion of } \\
\text { is not required. }\end{array}$ & $\begin{array}{r}\text { Because } \\
\text { values } \\
\text { backgrounc } \\
\text { calcualtion } \\
\text { in not }\end{array}$ & $\begin{array}{l}\text { all uranium } \\
\text { are below } \\
\text { de.3.21 mg/kg), } \\
\text { of excess risk } \\
\text { required. }\end{array}$ \\
\hline
\end{tabular}

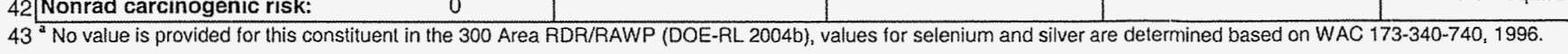

$44 \mathrm{BG}=$ background
$45 \mathrm{DC}=$ direct contact

$46 \mathrm{GW}=$ groundwater

47 HEIS = Hantord Environmental Intormation System

$49 \mathrm{PQL}=$ preacicical qu

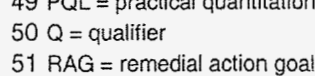

$51 R A G=$ remedial
$52 U=$ undelected

53 UCL = upper contidenco

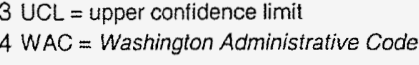




\section{Washington Closure Manford}

CALCULATION SHEET

Originator B. S. Wiegman $B \mathrm{~S}$

Project 300 Area Field Remediation

ob No. 14655

Calc. No. 0600X-CA-V0058

Rev. No.

$\frac{0}{05 / 09106}$

Subject $618-8$ Burial Ground Cleanup Verification 95\% UCL Calculations

Checked T.M. Blakley Sheet No. 4 of 5

1 Shallow Zone Sample Data (continued)

\begin{tabular}{|c|c|c|c|c|c|c|c|c|c|c|c|c|}
\hline \multirow{2}{*}{$\begin{array}{l}2 \\
3\end{array}$} & \multirow{2}{*}{$\begin{array}{c}\text { Sampling } \\
\text { Area }\end{array}$} & \multirow{2}{*}{$\begin{array}{c}\text { HEIS } \\
\text { Number }\end{array}$} & \multirow{2}{*}{$\begin{array}{c}\text { Sample } \\
\text { Date }\end{array}$} & \multicolumn{3}{|c|}{ Uranium-233/234 } & \multicolumn{3}{|c|}{ Uranium-235 } & \multicolumn{3}{|c|}{ Uranium-238 } \\
\hline & & & & $\mathrm{pCi} / \mathrm{g}$ & $\mathbf{Q}$ & MDA & $\mathrm{pCi} / \mathrm{g}$ & $\mathbf{Q}$ & MDA & $\mathrm{pCi} / \mathrm{g}$ & $\mathbf{Q}$ & MDA \\
\hline 4 & $\overline{A 1}$ & $\sqrt{11271}$ & $1 / 31 / 2006$ & 0.540 & & 0.27 & 0 & $\mathrm{U}$ & 0.31 & 0.439 & & 0.26 \\
\hline 5 & $\begin{array}{c}\text { Duplicate of } \\
\mathrm{J} 11271\end{array}$ & J11272 & $1 / 31 / 2006$ & 0.736 & & 0.26 & 0.081 & $\mathrm{U}$ & 0.31 & 0.401 & & 0.26 \\
\hline 6 & $\mathrm{~A} 2$ & $J 11273$ & $1 / 31 / 2006$ & 0.780 & & 0.35 & 0.056 & $\mathrm{U}$ & 0.42 & 0.734 & & 0.35 \\
\hline 7 & $\mathrm{~A} 3$ & $\mathrm{~J} 11274$ & $1 / 31 / 2006$ & 1.19 & & 0.40 & 0.314 & U & 0.48 & 0.363 & $U$ & 0.40 \\
\hline 8 & A4 & J11275 & $1 / 31 / 2006$ & 0.778 & & 0.25 & 0.078 & $U$ & 0.30 & 0.518 & & 0.25 \\
\hline
\end{tabular}

10 Statistical Computation Input Data

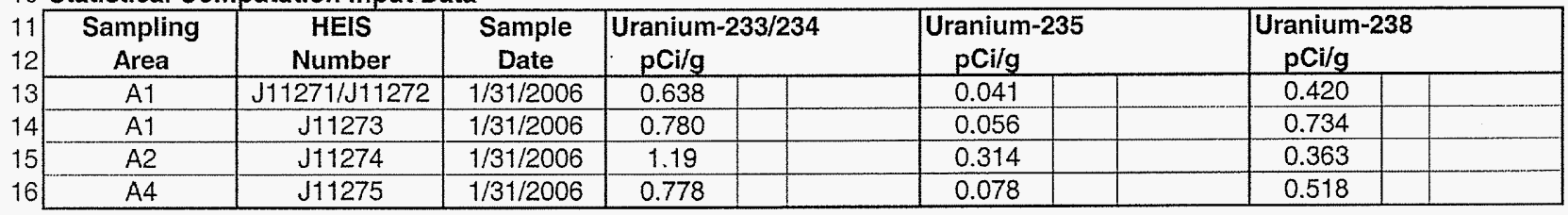

18 Statistical Computations

\begin{tabular}{|c|c|c|c|c|c|c|c|c|}
\hline \multirow[t]{2}{*}{19} & \begin{tabular}{|c|} 
\\
\end{tabular} & \multicolumn{2}{|c|}{ Uranium-233/234 } & \multicolumn{3}{|c|}{ Uranium-235 } & \multicolumn{2}{|c|}{ Uranium-238 } \\
\hline & Statistical value based on & $\begin{array}{r}\text { Radionu } \\
\text { Use no } \\
z-s\end{array}$ & $\begin{array}{l}\text { olide data set. } \\
\text { onparametric } \\
\text { statistic. }\end{array}$ & $\begin{array}{r}\text { Radionu } \\
\text { no }\end{array}$ & $\begin{array}{l}\text { e da } \\
\text { aran } \\
\text { tatis }\end{array}$ & $\begin{array}{l}\text { ata set. Use } \\
\text { metric } \\
\text { stic. }\end{array}$ & $\begin{array}{r}\text { Radionu } \\
\text { Use no } \\
z-\end{array}$ & $\begin{array}{l}\text { olide data set. } \\
\text { nparametric } \\
\text { tatistic. }\end{array}$ \\
\hline 21 & $\mathrm{~N}$ & 4 & & 4 & & & 4 & \\
\hline 22 & $\%<$ Detection limit & $0 \%$ & & $100 \%$ & & & $25 \%$ & \\
\hline 23 & mean & 0.847 & & 0.122 & & & 0.509 & \\
\hline 24 & st. dev. & 0.238 & & 0.129 & & & 0.163 & \\
\hline 25 & Z-statistic & 1.645 & & 1.645 & & & 1.645 & \\
\hline 26 & $95 \%$ UCL on mean & 1.04 & & 0.228 & & & 0.643 & \\
\hline 27 & max value & 1.19 & & 0.314 & $\mathrm{U}$ & & 0.734 & \\
\hline 28 & Statistical value & 1.04 & & 0.228 & $\mathrm{U}$ & & 0.643 & \\
\hline 29 & Background & 1.1 & & 0.11 & & & 1.1 & \\
\hline 30 & Statistical value above background & $0(<B G)$ & & 0.118 & $U$ & & $O(<B G)$ & \\
\hline
\end{tabular}

32 HEIS = Hanford Environmental Information System

$R A G=$ remedial action goal

$33 \mathrm{MDA}=$ minimum detectable activity

$34 \mathrm{NA}=$ not applicable

$\mathrm{UCL}=$ upper confidence limit

$35 \mathrm{Q}=$ qualifie

$W A C=$ Washington Administrative Code 
CALCULATION SHEET

Washington Closure Hanford

Originator B. S. Wiegman

Project 300 Area Field Remediation

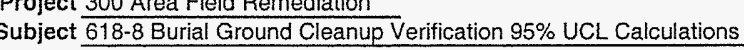

Date 05/09/06

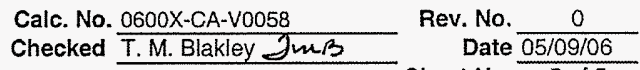

Calc. No. $\frac{0600 X-C A-V 0058}{\text { Rev. No. } \frac{0}{05 / 09 / 06}}$ Checked
T. M. Blakley JmB

Job No. 1465

Split-Duplicate Analysis

\begin{tabular}{|c|c|c|c|c|c|c|c|c|c|c|c|c|c|c|c|c|c|}
\hline \multirow{2}{*}{$\begin{array}{c}\text { Sampling } \\
\text { Area }\end{array}$} & \multirow{2}{*}{ HEIS Number } & \multicolumn{3}{|c|}{ Silver } & \multicolumn{2}{|c|}{ Arsenic } & \multicolumn{2}{|c|}{ Barium } & \multicolumn{3}{|c|}{ Cadmium } & \multicolumn{3}{|c|}{ Chromium } & \multicolumn{3}{|c|}{ Lead } \\
\hline & & $\mathrm{mg} / \mathrm{kg}$ & $Q$ & PQL & \begin{tabular}{l|l}
$\mathrm{mg} / \mathrm{kg}$ & $\mathrm{Q}$
\end{tabular} & PQL & $\mathrm{mg} / \mathrm{kg}$ & PQL & $\mathrm{mg} / \mathrm{kg}$ & Q & PQL & $\mathrm{mg} / \mathrm{kg}$ & Q & $P Q L$ & $\mathrm{mg} / \mathrm{kg}$ & Q & $\mathrm{PQL}$ \\
\hline$\overline{A 1}$ & J11271 & 0.15 & U & 0.15 & 3.4 & 0.36 & 81.3 & 0.02 & 0.07 & U & 0.07 & 10.4 & & 0.17 & 4.5 & & 0.33 \\
\hline Duplicate of $J 11271$ & $J 11272$ & 0.15 & U & 0.15 & 4.1 & 0.36 & 79.4 & 0.02 & 0.07 & U & 0.07 & 11.7 & & 0.17 & 4.2 & & 0.33 \\
\hline Split of J11271 & $\sqrt{11277}$ & 1.1 & $u$ & 1.1 & 3.5 & 1.1 & 94.9 & 21.3 & 0.53 & U & 0.53 & 8.3 & & 1.1 & 3.9 & & 1.1 \\
\hline \multicolumn{18}{|c|}{7 Shallow Zone Analysis: } \\
\hline \multicolumn{2}{|c|}{ TDL } & \multirow{2}{*}{\multicolumn{3}{|c|}{$\begin{array}{c}0.2 \\
\text { No-Ston (acceptable) }\end{array}$}} & \multicolumn{2}{|c|}{10} & \multicolumn{2}{|r|}{2} & \multicolumn{3}{|c|}{0.2} & \multicolumn{3}{|c|}{1} & \multirow{2}{*}{\multicolumn{3}{|c|}{5}} \\
\hline \multirow{4}{*}{ Duplicate Analysis } & Both > MDA? & & & & \multirow{2}{*}{\multicolumn{2}{|c|}{$\begin{array}{c}\text { Yes (continue) } \\
\text { No-Stop (acceptable) }\end{array}$}} & \multirow{2}{*}{\multicolumn{2}{|c|}{$\begin{array}{l}\text { Yes (continue) } \\
\text { Yes (calc RPD) }\end{array}$}} & \multicolumn{3}{|c|}{ No-Stop (acceptable) } & \multirow{2}{*}{\multicolumn{3}{|c|}{$\begin{array}{l}\text { Yes (continue) } \\
\text { Yes (calc RPD) }\end{array}$}} & \multicolumn{2}{|c|}{ Yes (continue) } & \\
\hline & Both $>5 \times$ TDL? & \multicolumn{3}{|c|}{ No-Stop (acceptable) } & & & & & & & & & & & \multirow{2}{*}{\multicolumn{3}{|c|}{ No-Stop (acceptable) }} \\
\hline & $\overline{R P D}$ & & & & & & \multicolumn{2}{|c|}{$2.4 \%$} & & & & \multicolumn{3}{|c|}{$12 \%$} & & & \\
\hline & Both > MDA? & \multicolumn{3}{|c|}{ No-Stop (acceptable) } & \multirow{2}{*}{\multicolumn{2}{|c|}{ Yes (continue) }} & \multirow{2}{*}{\multicolumn{2}{|c|}{$\begin{array}{l}\text { Yes (continue) } \\
\text { Yes (calc RPD) }\end{array}$}} & No-Stop & $(\mathrm{acc}$ & table) & \multirow{2}{*}{\multicolumn{3}{|c|}{$\begin{array}{l}\text { Yes (continue) } \\
\text { Yes (calc RPD) }\end{array}$}} & \multicolumn{3}{|c|}{ Yes (continue) } \\
\hline \multirow[t]{2}{*}{ Split Analysis } & Both $>5 \times T D L ?$ & & & & & & & & & & & & & & No-Stop & $(\mathrm{acc}$ & table) \\
\hline & RPD & & & & & & \multicolumn{2}{|c|}{$15 \%$} & & & & \multicolumn{3}{|c|}{$22 \%$} & & & \\
\hline
\end{tabular}

16 Shallow Zone Sample Results (continued)

\begin{tabular}{|c|c|c|c|c|c|c|c|c|c|c|c|c|c|c|c|c|c|}
\hline \multirow{2}{*}{$\begin{array}{l}17 \\
18\end{array}$} & \multirow{2}{*}{$\begin{array}{l}\text { Sampling } \\
\text { Area }\end{array}$} & \multirow{2}{*}{ HEIS Number } & \multicolumn{3}{|c|}{ Selenium } & \multicolumn{3}{|c|}{ Total Uranium } & \multicolumn{3}{|c|}{ Uranium-233/234 } & \multicolumn{3}{|c|}{ Uranium-235 } & \multicolumn{3}{|c|}{ Uranium-238 } \\
\hline & & & $\mathrm{mg} / \mathrm{kg}$ & Q & $\mathrm{PQL}$ & $\mathrm{mg} / \mathrm{kg}$ & Q & PQL & $\mathrm{pCl} / \mathrm{g}$ & $Q$ & MDA & $\mathrm{pCi} / \mathrm{g}$ & Q & MDA & $\mathrm{pCi} / \mathrm{g}$ & & MDA \\
\hline & A1 & J11271 & 0.81 & & 0.38 & 1.28 & & 0.017 & 0.540 & & 0.270 & 0.000 & $\mathrm{U}$ & 0.310 & 0.439 & & 0.260 \\
\hline & Duplicate of J11271 & $\sqrt{11272}$ & 0.76 & & 0.38 & 1.13 & & 0.017 & 0.736 & & 0.260 & 0.081 & $U$ & 0.310 & 0.401 & & 0.280 \\
\hline & Split of J11271 & $J 11277$ & 0.33 & $B$ & 1.6 & 3.28 & & 0.020 & 1.14 & & 0.053 & 0.078 & & 0.030 & 1.10 & & 0.053 \\
\hline \multicolumn{18}{|c|}{ Shallow Zone Analysis } \\
\hline & \multicolumn{2}{|c|}{ TDL } & \multirow{2}{*}{\multicolumn{3}{|c|}{$\frac{1}{\text { Yes (continue) }}$}} & \multirow{2}{*}{\multicolumn{3}{|c|}{$\begin{array}{l}1.0 \\
\text { Yes (continue) }\end{array}$}} & \multicolumn{3}{|c|}{1.0} & \multirow{2}{*}{\multicolumn{3}{|c|}{0.5}} & \multicolumn{3}{|l|}{1.0} \\
\hline & \multirow{3}{*}{ Duplicate Analysis } & Both > MDA? & & & & & & & \multirow{2}{*}{\multicolumn{3}{|c|}{$\frac{\text { Yes (continue) }}{\text { No-Stop (acceptable) }}$}} & & & & \multirow{2}{*}{\multicolumn{3}{|c|}{$\frac{\text { Yes (continue) }}{\text { No-Stop (acceptable) }}$}} \\
\hline & & Both $>5 \times$ TDL? & \multicolumn{3}{|c|}{ No-Stop (acceptable) } & \multicolumn{3}{|c|}{ No-Stop (acceptable) } & & & & \multicolumn{3}{|c|}{ No-Stop (acceptable) } & & & \\
\hline & & $\mathrm{RPD}$ & & & & & & & & & & & & & & & \\
\hline & \multirow{3}{*}{ Split Analysis } & Both > MDA? & \multirow{2}{*}{\multicolumn{3}{|c|}{ No-Stop (acceptable) }} & \multirow{2}{*}{\multicolumn{3}{|c|}{$\begin{array}{c}\text { Yes (continue) } \\
\text { No-Stop (acceptable) }\end{array}$}} & \multirow{2}{*}{\multicolumn{3}{|c|}{$\begin{array}{c}\text { Yes (continue) } \\
\text { No-Stop (acceptable) }\end{array}$}} & \multicolumn{3}{|c|}{ No-Stop (acceptable) } & \multicolumn{3}{|c|}{ Yes (continue) } \\
\hline & & Both $>5 \times$ TDL? & & & & & & & & & & & & & No-Stol & $(\mathrm{ac}$ & ptable) \\
\hline & & $R$ & & & & & & & & & & & & & & & \\
\hline
\end{tabular}

30 Note: The significance of the reported RPD values, including values greater than $30 \%$, is addressed within the Data Quality Assessment section of the Cleanup Verification Package for this site.

$31 \mathrm{~B}=$ analyte found in method blank

32 HEIS = Hanford Environmental Information System

$33 \mathrm{MDA}=$ minimum detectable activity

$34 \mathrm{PQL}=$ practical quantitation limit

$35 Q=$ qualifier

$36 \mathrm{RPD}=$ relative percent difference

$37 \mathrm{TDL}=$ target detection limit

$38 \mathrm{U}=$ undetected 


\section{DISTRIBUTION}

U.S. Department of Energy

Richland Operations Office

J. R. Franco

A3-04

S. L. Sedgwick

A7-80

D. C. Smith (5)

A3-04

RL Correspondence Control

A5-10

DOE-RL Public Reading Room

$\mathrm{H} 2-53$

Fluor Hanford, Inc.

J. P. Shearer (WIDS)

A0-21

Washington Closure Hanford

K. A. Anselm $\quad \mathrm{H} 9-02$

R. A. Carlson

$\mathrm{X} 0-17$

S. W. Clark

H9-01

F. M. Corpuz

L6-06

J. W. Darby

L6-06

L. A. Dietz

$\mathrm{HO}-23$

L. M. Dittmer

$\mathrm{H} 9-02$

M. J. Haass

L6-06

R. B. Kerkow

L6-06

J. E. Thomson

$\mathrm{HO}-23$

Records and Document Control

$\mathrm{H} 0-30$

Hanford Technical Library

P8-55 
CVP-2006-00006

Rev. 0

Distr-2 